\title{
MODEL RANCANG BANGUN TEOLOGI GEREJA CHARISMATIK WORSHIP SERVICE JAKARTA DALAM MENGHADAPI TREND ISU-ISU TEOLOGI PERTUMBUHAN GEREJA MASA KINI
}

\author{
Wasis Suseno \\ Sekoalh Tinggi Teologi Moriah, Tangerang, Indonesia \\ Email:wasisssn@gmail.com
}

\begin{abstract}
The aim of this study is to identify the issues facing the theology of church growth today. In the last period of tens years, the many negative teaching, has damage the teaching of the church. Many congregations of our are influenced by the negative doctrine. Charismatic Worship Service Church in Jakarta, has constructed its doctrine and theology in order to face the negative doctrine.
\end{abstract}

Keywords: trends issues theology, church growht, contruction theology

\begin{abstract}
ABSTRAK
Tujuan dari penelitian ini adalah mengidentifikasi masalah yang dihadapi trend isu-isu teologi pertumbuhan Gereja masa kini. Dalam kurun waktu puluhan tahun terakhir, banyak pengajaran negatif telah merusak ajaran Gereja. Banyak jemaat Gereja dipengaruhi oleh ajaran negatif tersebut. Gereja Charismatik Worship Service di Jakarta, telah merancang bangun teologi dalam menghadapi ajaran negatif.
\end{abstract}

Kata kunci: trend isu-isu teologi, pertumbuhan gereja, rancang bangun teologi

\section{PENDAHULUAN}

Rancang bangun teologi yang kuat dan benar akan berdampak pada ketahanan gereja dalam menghadapi isu-isu teologi dalam pertumbuhan gereja masa kini. Sama seperti ketika gereja mula-mula yang masih baru berdiri, yang juga berhadapan dengan berbagai isu teologi, ajaran-ajaran negatif, dari abad pertama hingga abad pertengahan, sampai pada abad ke-21. Isu-isu teologi mengambil muncul dalam model dan bentuk yang berbeda, berupaya mengeser ajaran yang sehat dan murni Alkitab, dengan ajaran yang menyimpang. Dinamika ini terus berlangsung, selama gereja tetap ada di dunia ini. ${ }^{1}$ Pada abad lampau gereja menghadapi berbagai ajaran seperti: Marcion, Montanus, Novatianis, Donatis, dan lain sebagainya. ${ }^{2}$ Kaena itu gereja tidak perlu terkejut dengan munculnya berbagai isu teologi yang membingungkan dan menyesatkan, yang disebut sebagai ajaran negatif. Menanggapi kondisi ini, yang diperlukan adalah kesiapan Gereja untuk memiliki model rancang bangun teologi yang kuat dan benar. Walker mengatakan, "Not every deviation from

Bdk. 2 Yohanes 1:4, 7, 9.

2 Th. Van den End, Harta dalam Bejana: Sejarah Gereja Ringkas (Jakarta: BPK Gunung Mulia, 1987), 21. 
tradition, however, could be called heretical practically speaking, therefore, the identification of what counted a heresy was a matter of papal decree."3

\section{A. Metodologi Penelitian}

Penulis mengunakan tiga aspek penelitian yakni: tujuan penelitian, tempat dan waktu penelitian, paradigma penelitian. Tujuan penelitian adalah memperlihatkan (menyuguhkan) konteks rancang bangun teologi pertumbuhan Gereja di abad ke-21 dalam kaitannya dengan munculnya berbagai fakta dan trend isu-isu teologi. Paradigma penelitian bukanlah paradigma positivisme atau scientific paradigm (paradigma ilmiah), ${ }^{4}$ melainkan paradigma naturalistik. Paradigma naturalistik atau paradigma alamiah adalah berdasarkan pada filsafat fenomenologis. Metode fenomenologis berusaha memahami perilaku manusia dari segi kerangka berpikir maupun tindakan orang-orang itu yang dibayangkan atau dipikirkan oleh orang-orang itu sendiri. ${ }^{5}$

Metode yang digunakan adalah kualitatif. Menurut John W. Creswell, "Penelitian kualitatif merupakan metode-metode untuk mengeksplorasi dan memahami makna yang-oleh sejumlah individu atau sekelompok orang - dianggap berasal dari masalah sosial atau kemanusiaan. Proses penelitian kualitatif ini melibatkan upayaupaya penting, seperti mengajukan pertanyaan-pertanyaan dan prosedur-prosedur, mengumpulkan data yang spesifik dari para partisipan, menganalisis data secara induktif mulai dari tema-tema yang khusus ke tema-

3 Williston Walker, A History of Christian Church (Harvard: Scribner Publisher, 1998), 300.

${ }^{4}$ Paradigma positivisme dapat dikarakteristikkan dengan tiga karakteristik berikut ini: 1) logika eksperimen dengan memanipulasi variabel yang dapat diukur secara kualitatif agar dapat dicari hubungan antara berbagai variabel; 2) mencari hukum universal yang dapat meliputi semua kasus, walaupun dengan pengolahan statistik dicapai tingkat probabilitas, dengan mementingkan sampling.

5 Lexy J. Moleong, Metodologi Penelitian Kualitatif. Edisi Revisi (Bandung: Penerbit PT Remaja Rosdakarya, 2010), 52. tema umum, dan menafsirkan makna data."6 Menurut Sugiyono, latar belakang sosial adalah sampel dan populasi penelitian. ${ }^{7}$ Dalam hal ini, yang menjadi komunitas (sampel dan populasi) penelitian ini adalah jemaat yang beribadah di Gereja GSJA Charismatik Worship service Jakarta.

\section{B. Hasil Penelitian}

Analisis tema merupakan seperangkat prosedur dari analisis taksonomi dan analisis komponen untuk memahami secara holistik atau menyeluruh permasalahan lembaga Gereja yang diteliti. Karena setiap permasalahan atau budaya organisasi terorganisasi terintegrasi dalam beberapa jenis pola yang lebih luas, peneliti menemukan beberapa pokok penting, berkaitan dengan hasil analisis taksonomi dan komponen yang telah dilakukan. Peneliti akan memaparkan hasil analisa tema, sebagai berikut:

\section{Warisan Rancang bangun Teologi Gereja CWS Jakarta}

Empat puluh satu tahun yang lampau, oleh Rev. Carl Chrisner merintis Gereja CWS, tepatnya tanggal 17 November 1974, dan telah meletakkan landasan yang kuat. Ada dua dasar Alkitab sebagai alasan berdirinya Charismatic Worship Service: pertama, Zakharia 4:6, "Inilah Firman Tuhan kepada Zerubabel bunyinya: Bukan dengan keperkasaan dan bukan dengan kekuatan, melainkan dengan roh-Ku, Firman Tuhan semesta Alam"; kedua, Kisah Para Rasul 1:8, "Tetapi kamu akan menerima kuasa, kalau Roh Kudus turun ke atas kamu."

Seiring dengan pertumbuhan dan perkembangannya, Gereja CWS tidak lepas dari rancang bangun teologi internalnya. Ada empat inti rancang bangun teologi Gereja CWS saat ini: Pertama: Keselamatan. Setelah seseorang menerima Tuhan Yesus

6 John W. Creswell, Research Design: Pendekatan Metode Kualitatif, Kuantitatif, dan Campuran, terj. Achmad Fawaid dan Rianayati K. Pancasari (Yogyakarya: Pustaka Pelajar, 2016), 4-5.

\footnotetext{
7 Sugiyono, Metode Penelitian Pendidikan Pendekatan Kuantitatif, Kualitatif, dan $R \quad \& \quad D$
} (Bandung: Alfabeta, 2008), 399. 
sebagai Tuhan dan Juru Selamat, maka ia harus senantisa (setiap hari) dipenuhi Roh kudus, sebagai tanda bahwa ia dipimpin Roh Kudus. Kedua: Baptisan Roh Kudus. Sebagai tanda awal bahwa seseorang dipenuhi Roh Kudus, maka ia mengalami pengalaman rohani secara nyata dalam kehidupannya sehari-hari. Ketiga: Karunia-karunia Roh Kudus. Setelah dipenuhi Roh Kudus, maka orang percaya telah diberikan karuniakarunia Roh Kudus (Kis. 1:8). Keempat: Gereja Sebagai Tubuh Kristus. Gereja CWS Jakarta, mendorong, membimbing dan menyediakan tempat bagi orang percaya (jemaat) untuk mempraktekkan kebenaran Friman Allah sebagai suatu gaya hidup. Gaya hidup kerajaan Allah yang ditumbuhkan melalui komunitas Gereja lokal.

Dari keempat unsur model rancang bangun teologi, terbukti bahwa Gereja CWS Jakarta telah menjadi berkat bagi banyak jemaat, bermultipikasi atau pelipat gandaan jemaat dengan adanya 30 lebih cabang Gereja CWS yang tersebar di berbagai wilayah Indonesia, di mana cabang-cabang yang ada mewarisi unsur model rancang bangun teologi yang tidak jauh berbeda dengan Gereja CWS Pusat.

\section{Merevisi Rancang Bangun Teologi Gereja}

Gereja CWS tidak hanya melihat empat unsur model rancang bangun yang telah ada (Baptisan Roh Kudus, Karunia-karunia Roh, Keselamatan, dan Gereja sebagai Tubuh Kristus) sebagai bagian signifikan dari pertumbuhan Gereja, tetapi juga melihat secara komprehensip - selaras dengan perkembangan dan isu di setiap zamanrancang bangun teologinya, seperti yang dikatakan dalam Alkitab Matius 9:17, "Begitu pula anggur yang baru tidak diisikan ke dalam kantong kulit yang tua, karena jika demikian kantong itu akan koyak, sehingga anggur itu terbuang dan kantong itupun hancur. Tetapi anggur yang baru disimpan orang dalam kantong yang baru pula, dan dengan demikian terpeliharalah kedua-duanya."

Pengajaran Tuhan Yesus ini sebenarnya ditujukan untuk menepis kritik orang Yahudi, mengapa Dia dan murid-murid-Nya tidak berpuasa, sedangkan Yohanes Pembabtis dan pengikutnya berpuasa. Kepada mereka Tuhan Yesus menjelaskan bahwa Dia adalah mempelai pria, bagaimana para sahabat-Nya harus berpuasa/berpuasa sementara. Pengajaran Tuhan Yesus tentang hal ini berkaitan dengan konsep Perjanjian Lama, di mana orang-orang Lewi bertindak selaku imam yang melaksanakan semua upacara sesuai dengan peraturan-peraturan yang ditetapkan Allah secara rinci. Ada dua pemahaman yang berbeda: orang Farisi masih memakai sudut pandang Perjanjian lama, sedangkan Tuhan Yesus tidak.

Yang dimaksud kirbat dalam teks firman Tuhan adalah Gereja Tuhan; bukan gedung, tetapi persekutuan orang-orang percaya yang diikat oleh satu Tuhan, satu iman, satu baptisan (Ef. 4:5). Gereja CWS sejatinya telah mengikuti gerakan Allah, sebagaimana tampak dari gerakan-gerakan berikut ini:

1. Tahun 1900: Gerakan Pentakosta, mengedepankan Karya Roh Kudus.

2. 1950: Gerakan Pekabaran Injil ditandai dengan TL. Osborn, Oral Robert, |Morris Cerullo, dan lain sebagainya.

3. Tahun 1960: Gerakan Social Gospel.

4. Tahun 1970: Gerakan Doa Global, bahasa lidah, ditandai munculnyan pendoa syafaat, dan Jaringan Doa.

5. Tahun 1980: Gerakan Kharismatik dan Penyembahan \& Kenabian

6. Tahun 1990: Gerakan Apstolik (Kerasulan)

7. Abad ke 21 ini, Gerakan Allah memakai pola kepemimpinan di Gereja-gereja lokal, misalnya Rev. Dr. Kong Hee city Harvest Singapore, Ps. Jeffry Rachmat, dan Jakarta Praise Community Church Jakarta (JPCC).

Berdasarkan fakta sejarah di atas, munculnya gerakan pembaharuan Gereja terus terjadi secara dinamis. Bila dilihat dari timeline di atas, Gereja CWS masuk dalam kategori kegerakan tahun 1980-an. Dan dengan demikian, Gereja CWS tetap perlu membuka diri dalam perubahan zaman yang ada. Model rancang bangun teologinya perlu direvisi, agar mengikuti dinamika gerakan 
Allah, tanpa meninggalkan kebenaran yang bersumber pada Alkitab.

\section{Antisipasi Trend Isu-isu Teologi Pertumbuh- an Gereja Masa Kini}

Dengan berkaca pada arus pengajaran atau gerakan pembaharuan yang berkembang pada masa kini, maka Gereja CWS jemaat telah bersikap mandiri. Hal ini terlihat ketika Yayasan Mahanaim yang diketuai oleh Iin Cipto, mengadakan acara Tahun Yobel pada bulan Oktober 2015. Seluruh Jemaat Gereja CWS dimobilisasi dan difasilitasi untuk mengikuti acara tersebut.

Beberapa poin penting dari antisipasi disebabkan oleh dua hal berikut ini: Pertama, lemahnya peranan hamba Tuhan di Gereja CWS Jakarta. Hamba Tuhan atau Pendeta, perlu lebih sering memberikan ajaran atau doktrin (teologi) yang sehat, melalui mimbar Gereja pada ibadah Minggu, sehingga melalui khotbah yang menekankan pengajaran Alkitab secara mendalam dapat memberikan pengaruh. Umumnya tema-tema khotbah sepanjang tahun hanya seputar karya Roh Kudus, berkat, dan iman. Dalam hal ini tidak terjadi keseimbangan, di mana tema-tema karya Roh Kudus diberi porsi yang lebih banyak kan dengan dibanding tema-tema seperti keselamatan, eklesilogi, pemahaman teologi sistematika, lainnya seperti Kristologi, Doktrin Allah, Eskatologi, dan lain sebagainya. Kedua, model rancang bangun teologi Gereja yang Baru. Gereja CWS Jakarta perlu menyusun kembali model rancang bangun teologianya dengan memperhatikan unsur-unsur trend isu-isu teologi pertumbuhan Gereja masa kini. Bukan untuk meniru atau mengikuti, tetapi lebih tepat: mengikuti Gerakan Allah melalui dan di dalam Gereja-Nya. Di Gereja CWS Jakarta, perlu bertindak mengkaji, merevisi, dan merancang kembali bangunan teologinya sesuai dengan konteks zaman: memperkuat Pneumatologi, Eklesiologi, dan Soteriologi, dan aspek-aspek lain yang mendukung, seperti gerakan pekabaran Injil dan misi.

\section{Pembahasan}

\section{Apa Rancang Bangun Teologi itu?}

Menurut Kamus Besar Bahasa Indonesia (KBBI), kedua kata ini merupakan gabungan kata yang pemaknaannya terkait dengan bangunan. Kedua kata ini dapat juga dipahami secara terpisah agar pemahamannya lebih luas. Kata 'rancang' berarti mengatur segala sesuatu sebelum bertindak. Mengerjakan atau melakukan sesuatu untuk merencanakan; sedangkan kata 'bangun' berarti sesuatu yang didirikan. ${ }^{8}$ Dengan demikian rancang bangun dalam konteks ini berarti merencanakan atau mendesain sesuatu yang akan dibuat. Bila dikaitkan dengan rancang bangun teologi gereja, maka rancang bangun yang dimaksud menunjuk pada dasar teologi yang dibuat untuk membangun pemahaman pengajaran gereja lokal.

\section{Pengertian Rancang Bangun Teologi}

Dari hasil analisis data taksonomi, komponen dari Pendeta CWS Pusat dengan Gembala Cabang CWS (yang merupakan representatif Gereja CWS), ditemukan jawaban tentang apa yang dimaksud rancang bangun Teologi, yakni: (1) Menyusun pemahaman teologi dengan konteks Gereja lokal; (2) Pemahaman-pemahaman teologia alkitabiah; (3) aturan-aturan yang disusun. Sedangkan dari para representasi Gereja CWS Jakarta, ditemukan pendapat tentang rancang bangun teologi, yakni: kerangka dasar atau grand design ilmu ke-Tuhanan dalam implikasi logos dan rhema. Di sini tidak dipahami secara benar tentang apa yang dimaksud dengan rancang bangun teologi. Istilah rancang bangun menurut informan adalah satu kata yang membingungkan atau jarang didengar di dalam khotbah dan pelayanan Gereja.

Para Pendeta Gereja CWS Jakarta yang tidak memiliki pemahaman tentang teologi Gereja lokal, dapat dilihat dari analisa komponen sebagai triangulasi data. Seharusnya pengertian rancang bangun teologi dapat dijelaskan secara utuh, sesuai dengan apa yang menjadi kajian dalam berteologi. Pemahaman teologi didasarkan

8 Kamus Besar Bahasa Indonesia (Jakarta: Departemen Pendidikan Nasional, 2001). 
pada Alkitab (apa yang dinyatakan oleh Allah). Penyataan Allah sendiri bukan berangkat dari pengetahuan dan kemampuan manusia. Jika Allah tidak menyatakan diri kepada ciptaan-Nya, maka tak mungkin mereka mengenal Dia. Menurut Stevri Lumintang, teologi yang lengkap dan seutuhnya terdiri atas empat: (1) teologi adalah mengenal Allah, (2) teologi adalah bersekutu dengan Allah, (3) teologi adalah menjadi serupa dengan Allah, dan (4) teologi adalah melakukan kehendak Allah. Keempat unsur tersebut menjelaskan arti teologi secara teologis-praktis. ${ }^{9}$

\section{Signifikansi Rancang Bangun Teologi untuk Gereja Lokal}

Secara umum, beberapa informan yang diteliti memberikan informasi bahwa ancang bangun teologi lokal sangat penting, karena dihubungkan dengan pertumbuhan jemaat di dalam suatu Gereja lokal. Gereja yang memiliki rancang bangun teologi yang kuat, akan menghasilkan Gereja atau jemaat yang kuat, mengalami pertumbuhan. Akan tetapi dalam kenyataan di Gereja CWS Jakarta, rancang bangun teologi tidak terlalu kuat. Bila dikatakan sangat lemah, maka penyebabnya karena landasan teologinya tidak kuat. Hal tersebut dapat dilihat dalam khotbah-khotbah Minggu, pengajaran firman seputar karya Roh Kudus, iman, dan berkat, tetapi jarang sekali membahas mengenai doktrin yang berkaitan dengan teologia Gereja lokal.

Karena jarang membahas aspek yang berkaitan dengan rancang bangun teologi Gereja lokal, maka menyebabkan jemaat mudah terombang-ambing karena tidak memiliki pijakan atau landasan pengajaran firman Tuhan yang kuat; kecenderungan yang selalu ditekankan adalah "mengalir saja, mengikuti Roh Kudus."

\section{Mengapa Rancang Bangun Teologi?}

9 Stevri Indra Lumintang, Keunikan Teologi Kristen di Tengah Kepalsuan (Batu: Departemen Literatur PPII, 2013), 184.
Rancang bangun teologi penting bagi gereja lokal. Rancang bangun itu mencakup beberapa aspek berikut ini:

\section{Unsur teologi yang menjadi nilai-nilai utama di Gereja lokal}

Kata "teologi" berasal dari dua kata Yunani, yakni: theos yang berarti "Allah" dan logos "kata/firman."10 Penggabungan kedua kata ini, menjadi "teologi" dipahami sebagai sebuah studi tentang Allah. Lot Natigor Sihombing mengatakan, teologi adalah"usaha untuk menafsirkan, merumuskan, mengajarkan dan memberitakan penyataan Allah di dalam Alkitab". ${ }^{11}$

Conner dalam bukunya menulis, "teologi berarti ilmu mengenai Allah, mengenai doktrin-doktrin agama dan mengenai hal-hal yang berkaitan dengan Allah". ${ }^{12}$ Maka dalam teologi fakta yang berkaitan dengan Allah dan Firman-Nya yang disajikan dalam metode yang tersusun dan logis. ${ }^{13}$ Daniel Lukas Lukito dalam bukunya menulis bahwa teologi diberi pengertian secara sempit yakni usaha untuk meneliti iman Kristen dari aspek doktrinnya. ${ }^{14}$ Lukito memberikan kesimpulan bahwa teologi adalah pembicaraan secara rasional tentang Allah dan pekerjaan-Nya, dalam arti pembicaraan yang rasional tentang Allah sebagai titik tolak penemuan yang sine que non dan prima facie yaitu Alkitab sebagai titik tolak penemuannya. ${ }^{15}$ Jadi teologi berarti percakapan tentang Allah atau lebih lengkapnya pemikiran tentang Allah yang dinyatakan dalam pernyataan-pernyataan tentang Allah." "16 Lumintang dalam bukunya yang berjudul Keunikan Teologi Kristen Di Tengah Kepalsuan menjelaskan secara

10 Lumintang, Keunikan Teologi Kristen di Tengah Kepalsuan, 184.

11 Lotnatigor Sihombing, Bahan Ajar Teologi: The Doctrin of God (Batu: 1989), 1.

${ }^{12}$ Kevin J. Conner, A Practical Guide to Christian Belief: Pedoman Praktis tentang iman Kristian (Malang: Gandum Mas, 2004), 15.

${ }^{13}$ Conner, A Practical Guide to Christian Belief, 33.

14 Daniel Lukas Lukito, Pengantar Teologi Kristen (Kalam Hidup, Bandung, 1996), 11.

${ }^{15}$ Lukito, Pengantar Teologi Kristen, 12.

16 J. I. Pakcer, God's Plans for You (Jakarta: Momentum, 2004), 1. 
historis istilah teologi di dunia berasal dari ibu bahasa teologi yakni bahasa latin. ${ }^{17}$ Baginya, teologi adalah suatu pemikiran atau perkataan atau refleksi mengenai Allah dari Allah dan oleh Allah. ${ }^{18}$

Karena itu dapatlah dikatakan bahwa, rancang bangun teologi gereja lokal, menjelaskan secara sistematis dasar-dasar pengajaran mengenai kebenaran-kebenaran utama, mengenai iman Kristen dijelaskan dalam Alkitab dengan mengkajinya secara sistematika, sehingga menghasilkan nilai-nilai teologi yang sangat bermanfaat bagi kehidupan gereja gereja lokal.

\section{Sumber-sumber Teologi}

Selain Alkitab sebagai sumber utama rancang bangun teologi di gereja GSJA Charismatic Worship Service (CWS), sumber Teologi yang lainya adalah melihat kepada doktrin warisan yang sudah ada, misalnya dengan mempelajari apa yang sudah dihasilkan di dalam teologi biblika, historika, dan filsafat. Teologi biblika secara khusus menelusuri perkembangan suatu tema tertentu. Teologi historika memberikan kontribusi dengan memperlihatkan berbagai penafsiran Alkitab yang pernah dilakukan gereja atau teolog di masa yang lampau; sedangkan teologi filsafat membantu merelevankan pemikiran teologis dengan cara kritis memaparkan isi teologi kepada dunia kontemporer.

\section{Pendekatan Hermeneutik Teologi}

Hermeneutik gereja GSJA CWS berpegang pada penafsiran GramaticalHistorical Interpretation (Sejarah penafsiran tata bahasa). Terkait dengan hal ini maka teologi tradisional memahami hermeneutiknya dalam tiga hal, antara lain: pertama, hermeneutik alkitabiah (biblikal) memberikan perhatian lebih kepada penafsiran, pengertian dan makna dari teks Alkitab. Kedua, memperhatikan gaya bahasa, arti, dan mengomunikasikan makna teks tersebut. Ketiga, penafsiran itu sendiri dimulai dari

\footnotetext{
17 Lumintang, Keunikan Teologi Kristen di Tengah Kepalsuan, 7.

${ }^{18}$ Lumintang, Diktat Teologi, 7.
}

Alkitab. Karena cara mendapatkan the original meaning dari sebuah teks haruslah kembali kepada teks yang asli (bahasa), latar belakang (sejarah, kondisi geografis, kehidupan masyarakat, kebudayaan), konteks dekat dan jauh dari teks, melalui eksegese dan menemukan makna dari teks tersebut untuk pendengar masa kini (aplikasi). Hermeneutik yang benar bertolak dari author centered (maksud penulis awal) ke text centered (Teks Alkitab) dan terakhir ke reader centered (aplikasi kekonteks sekarang). ${ }^{19}$

\section{Sistem Teologi}

Seseorang tidak dapat mengenal wahyu Allah yang seutuhnya seperti yang dinyatakan dalam Alkitab apabila keseluruhan isi Alkitab itu tidak dipelajari sebagai suatu sistem secara keseluruhan (totalitas). ${ }^{20}$ Lumintang dalam bukunya keunikan teologi Kristen di tengah kepalsuan juga meyakini bahwa keyakinan yang tidak sistematik sangat mungkin akan tumpang tindih dan inkonsistensi bahkan bertentangan. Keyakinan Kristen adalah keyakinan yang sistematis yang berawal dari iman kepada pengertian, berlanjut pada pertobatan cara berpikir. Keyakinan tersebut bertolak dari Allah dan bermuara pada kedaulatan-Nya. Keyakinan teologis tersebut merupakan dasar dari keyakinan teologis dan dasar dari kehidupan yang sehat. ${ }^{21}$

\section{Doktrin}

Menurut Conner, doktrin adalah sesuatu yang diajarkan, pengajaran, perintah, prinsipprinsip agama yang diajarkan atau lebih harafianya, mengajarkan hakikat. Lebih lanjut, tambahnya, para teolog menggunakan istilah doktrin untuk merujuk kepada kebenaran-kebenaran Firman Allah yang diajarkan. Kata doktrin digunakan 56 kali dalam Alkitab bahasa Inggris yang direvisi. Salah satunya disebutkan dalam Kisah Para Rasul 2:42 di mana gereja mula-mula tetap

19 Hasan Sutanto, Hermeneutik: Prinsip dan Metode Penafsiran Alkitab (Malang: SAAT, 1986), 2.

${ }^{20}$ Lukito, Pengantar Teologi Kristen, 17.

21 Lumintang, Keunikan Teologi Kristen di Tengah Kepalsuan, 52. 
berpegang teguh pada ajaran para rasul."22 Demikian juga ditegaskan oleh Rasul Paulus: "Dengan mengingatkan selalu hal-hal itu kepada saudara-saudara kita, engkau akan menjadi seorang pelayanan Kristus yang baik, terdidik dalam soal-soal iman kita dan dalam ajaran yang sehat yang telah engkau ikuti selama ini (1 Tim. 4:6). Hal ini membuka pemahaman kita bahwa doktrin yang sehat yang bersumber dari Alkitab itu sangat penting bagi pelayanan dan pertumbuhan kualitas Gereja.

\section{Sumber-sumber Rancang Bangun Teologi}

Berdasarkan data yang diperoleh dari informan, dapat dianalisis mengenai sumber-sumber apa saja yang digunakan untuk menyusun rancang bangun teologi. Selain Injil, salah satu yang disebut juga adalah konteks budaya. Hal ini sejalan dengan pandangan Robert J.

Schreiter yang
menjelaskan tiga unsur teologi lokal atau rancang bangun, yaitu: Injil, Gereja, dan Budaya. Selain itu, sumber yang lebih penting dan utama adalah Alkitab. ${ }^{23}$ Pada kenyataannya, di Gereja CWS Jakarta, pemahaman Alkitab cenderung tidak mendalam - adanya keterbatasan pemahaman terhadap (ajaan) Alkitab-sehingga sangat sulit diharapkan untuk dapat menyusun model rancang bangun teologi Gereja yang baru.

\section{Menyusun Rancang Bangun Teologi}

Peranan pemimpin sangat penting. Kepemimpinan di Gereja CWS disebut (atau identik) dengan "Gembala Senior". Untuk itu, dalam menyusun rancang bangun teologi

${ }^{22}$ Kevin J. Conner, A Practical Guide to Christian Belief: Pedoman Praktis tentang Iman Kristian (Malang: Gandum Mas, 2004), 15.

23 Lumintang, Keunikan Teologi Kristen di Tengah Kepalsuan, 184.
Gereja CWS Jakarta, tidak hanya didasarkan pemikiran satu orang saja tetapi lebih kepada komitmen bersama, termasuk perlu memahami secara jelas sumber-sumber teologi, aspek pemahaman hermeunetik, dan teologi sistematika. ${ }^{24}$

Berdasarkan data yang diperoleh dapat dianalisis mengenai bagaimana menyusun rancang bangun teologi Gereja lokal. Memasuki usia Gereja yang ke-41 tahun, Gereja CWS Jakarta masih tetap memegang warisan rancang bangun teologi dari para pendiri. Gereja CWS kurang mampu mengikuti dinamika perubahan zaman, di mana Tuhan bergerak dan memakai Gereja sesuai zamannya. Selama 40 tahun, Gereja CWS tetap bertahan dengan rancang bangun teologi yang diwariskan, tanpa ada upaya untuk menyusun rancang BERSEKUTU bangun teologi yang baru, mengikuti gerakan Allah dari masa ke masa.

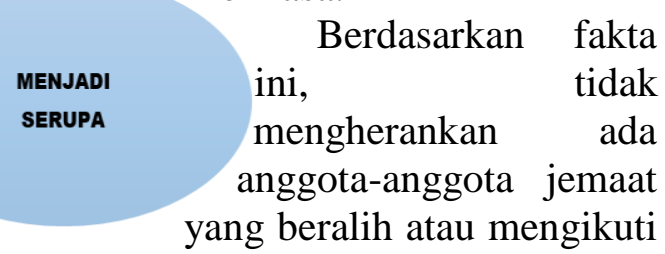
ajaran-ajaran baru yang lebih menarik dan inovatif, segar. Jemaat merasa tidak mendapatkan apa-apa ketika mereka mengikuti ibadah-ibadah di Gereja. Kondisi ini tentunya tidak bisa dibiarkan (didiamkan), tetapi perlu ada upaya yang konkret dan serius untuk mencari solusi, dan dengan berani melakukan perubahan-perubahan yang konstruktif.

\section{Fakta dan Trend Isu-isu Teologi Masa kini}

Sekarang perlu melihat fakta dan trend isu teologi masa kini, dalam kaitannya dengan (pelayanan) Gereja. Pemikiran dan gaya hidup yang pragmatis, menjadi bagian yang tidak terpisahkan di abad ke-21 ini. Misalnya masyarakat Amerika, sebagai pusat trend setter dunia, segala trend yang berkembang,

\footnotetext{
${ }^{24}$ Lukito, Pengantar Teologi Kristen, 11.
} 
berdampak ke bagian belahan dunia yang lain, tidak terkecuali di Asia, maupun di Indonesia. Dalam konteks ini, gaya hidup-di Amerika-yang metropolis dan pragmatis, dipengaruhi oleh American Ethos ${ }^{25}$, di mana aliran ini dibentuk oleh filsafat pragmatis yang salah satunya digagas oleh John Dewey (1859-1952).

Dalam perilaku keseharian, pragmatisme menjadi nilai-nilai vital kehidupan yang ikut mengatur perilaku dan cara pandang masyarakat, terutama dalam berhubungan dengan orang lain. ${ }^{26}$ Bagi masyarakat Amerika, sesuatu yang penting, sebagaimana ditekankan oleh aliran filsafat ini, adalah konkrit, terukur, dan jelas penggunaanya. Dalam sudut pandang filsafat pragmatisme, kebenaran sebuah teori dan pengetahuan harus bisa dibuktikan melalui pengalaman dan tindakan manusia. Melalui pengalaman tersebut, kebenaran dapat diuji untuk diterima atau ditolak. Bukan hanya soal pragmatisme, abad ke-21 juga mengantar manusia untuk menjadi semakin rasional di dalam memahami segala sesuatu. Rasionalisme adalah sebuah pandangan filsafat yang menekankan rasio manusia sebagai penentu kebenaran. ${ }^{27}$ Dalam pandangan ini, segala sesuatu dihakimi berdasarkan akal dan pikiran. Jika sesuatu mendapat penjelasan secara rasional, maka sesuatu itu dapat diterima. Demikian sebaliknya. Aliran ini pada awalnya dikembangkan oleh Descartes (1596-1650) seorang filsuf Perancis sebagai responnya terhadap berbagai pergumulan dunia. ${ }^{28}$

${ }^{25}$ W. T. Jones dan Robert J. Fogelin, A History of Western Philosophy: The Twentieth Century to Quine and Derrida (Orlando: Harcourt Brace College Publishers, 1997), 35.

${ }^{26}$ Albertine Minderop, dalam Pragmatisme dalam Falsafah Masyarakat Amerika (Jakarta: Obor, 2005), 20-21.

${ }^{27}$ Colin Brown, Filsafat dan Iman Kristen. Jilid 1 (Surabaya: Momentum, 2008), 63.

${ }^{28}$ Aliran filsafat rasionalisme muncul pertama kali sebagai sebuah gerakan di daratan Eropa (kecuali Inggris). Tokoh-tokoh lain yang mengembangkan aliran ini adalah Spinoza (1632-1677), G. W. Leibniz (1646-1716) dan Blaise Pascal (1623-1662).
Satu aliran terakhir yang memberi ciri abad ke-21 adalah empirisme. ${ }^{29}$ Aliran ini menekankan pengalaman sebagai titik tolak kebenaran. Empirisme adalah kebenaran yang diterima melalui pengalaman, percobaan, penemuan, dan pengamatan yang telah dilakukan. Menurut Brown, berbeda dengan orang rasionalis yang berusaha menegakkan sistem filsafat dengan memakai pikiran berdasarkan kebenaran-kebenaran yang menurut dugaan orang terbukti dengan sendirinya, penekanan empiris justru pada pengalaman yang datang melalui indera manusia. $^{30}$ Beberapa tokohnya antara lain John Locke (1632-1704), George Berkeley (1685-1753) dan David Hume (1711-1776).

\section{Problem Gereja Menghadapi Trend Isu-Isu Teologia Pada Masa Kini}

Berangkat dari fakta di atas, pragmatisme, rasionalisme dan empirisme menjadi tanda awas bagi Gereja sekaligus menjadi tantangan tersendiri, tentang bagamaiman Gereja menyikapinya. Bagaimana dengan Gereja Charismatik Worship service Jakarta dalam menghadapi fakta tersebut? Untuk memahami hal ini, beberapa perspektif berikut ini dapat menjadi pemahaman bersama.

Zaman yang berubah menuntut penyesuaian. Gereja perlu melakukan respons kritis terhadap perubahan yang sedemikian cepat, yang berlangsung di sekitarnya. Gereja tentu perlu menunjukkan sikap mentransformasi diri sendiri dari waktu ke waktu, seiring dengan tantangan di setiap zamannya. Setiap Gereja bertanggung jawab atas sejarahnya, dan terus mengupayakan perberkembangan secara serius.

Menurut Th. van den End, sejarah Gereja adalah kisah tentang perkembanganperkembangan dan perubahan yang dialami oleh Gereja selama di dunia ini, yaitu kisah

${ }^{29}$ Istilah ini berasal dari kata Yunani empeiria (=pengalaman) dan empeirikos (=berpengalaman). Sejak abad kesembilan belas dan seterusnya, kata itu telah dipergunakan untuk menunjukkan bermacammacam filsafat yang menekankan pengalaman sebagai sumber pengetahuan. Gerakan ini dimulai di Inggris, hampir bersamaan dengan mulainya aliran rasionalisme di Eropa. 
tentang pergumulan antara Injil dengan bentuk-bentuk yang dipakai untuk mengabarkan Injil. ${ }^{31}$ Van den End menganalogikan Gereja sebagai sebuah pohon yang awalnya merupakan sebuah tunas kecil, kemudian tumbuh dengan batang yang besar dengan dahan, cabang dan ranting yang banyak, tidak sama ukurannya dan bentuknya. Begitu pula halnya dengan gereja-Gereja yang lahir dari jemaat pertama yang berlainan: dalam hal tata Gereja, tata kebaktian, dan ajaran. Tetapi semuanya itu berakar dalam tanah yang sama. ${ }^{32}$

Sejak zaman pantekosta berlangsung, Gereja mengalami perubahan yang sangat pesat, baik dari segi jumlah pengikut, tata cara, organisasi, dan juga ajaran-ajarannya (dalam hal ini katakan sebagai teologinya). Bahkan hingga kini, Gereja tumbuh di dalam berbagai denominasi dan aliran yang berbedabeda satu dengan lainnya. Hal tersebut membuktikan bahwa Gereja dalam sejarahnya telah mengalami perkembangan yang demikian pesat sebagai tubuh Kristus di dunia. Dalam perkembangan itu sendiri, Gereja bukan hanya bertahan membangun dirinya dari dalam, juga mempertahankan dirinya dari berbagai musuh yang secara sistematis berniat menghancurkan Gereja terutama dalam menghadapi ajaran-ajaran yang tidak sesuai dengan kebenaran Alkitab. Sejarah membuktikan, bahwa Gereja mampu bertahan dari gejolak-gejolak yang berlangsung secara internal.

Mengenai hal ini, Paulus Daun mengatakan, bahwa "ancaman dari dalam ini bagaikan musuh dalam selimut yang tanpa disadari akan membawa efek fatal bagi iman kepercayaan Kristiani.ancaman dari dalam ini berbentuk ajaran-ajaran (doktrin) yang menyesatkan atau bidat-bidat yang mau menyelewengkan ajaran murni Alkitab." 33 Setiap masa yang berbeda akan menghasilkan tantangan dan persoalan yang berbeda pula. Demikian juga di abad ke-21 ini, yang dicirikan sebagai sebuah masa di mana orang

\footnotetext{
${ }^{31}$ Van den End, Harta dalam Bejana, 7.

${ }^{32}$ Van den End, Harta dalam Bejana, 7.

${ }^{33}$ Paulus Daun, Bidat Kristen dari Masa ke Masa (Manado: Yayasan Daun Family, 1999), 3.
}

akan semakin pragmatis, rasional, dan empiris. Gereja akan menghadapi tantangan tersendiri yang menuntut respons Gereja untuk mempersiapkan diri menghadapi semua itu. ${ }^{34}$ Injil yang menjadi sentral pemberitaan Gereja, tentu akan banyak mengalami gugatan dari sudut pandang ilmu pengetahuan dan pendekatan rasionalistik. Hal ini juga sekaligus merupakan tantangan bagi Gereja untuk semakin aktual dan mewujudkan perannya secara nyata, di tengah masyarakat modern yang justru sedang bergerak ke arah secular.

Penyesuaian apa yang dapat dilakukan oleh Gereja untuk bisa bertahan dan bertumbuh? Paling tidak ada dua hal: Pertama, penyesuaian strategis, untuk merubah apa yang dipandang perlu dalam hal ajaran, tata cara, organisasi, dan strategi pemberitaan Injil. Kedua, penyesuaian yang bersifat konsolidatif, sebuah usaha untuk merapatkan barisan dan memperkokoh ajaran Gereja (yakni Injil) di tengah situasi dan alam pikiran manusia yang secara tegas menarik batas antara hal-hal dunia (yang nyata, yang dimengerti dan real) dengan hal-hal rohani (yang dianggap abstrak dan tidak nalar). Untuk hal yang kedua ini, Gereja perlu membangun kembali satu teologi yang benarbenar berdiri atas kebenaran firman. ${ }^{35}$

Dari fakta di atas, ada upaya untuk membangun satu teologi yang benar-benar kuat untuk menghadapi trend isu-isu teologi, dengan mempertahamnkan identitas teologi pertumbuhan Gereja. Kekuatan ini akan menjadi semakin potensial bagi Gereaj untuk menghadapi tantangan di abad ke-21 ini. Beberapa fakta berikut ini adalah mengenai tantangan (positif dan negatif) yang dapat menjadi penghalang, penghambat, atau penguat bagi Gereja, dan dari fakta ini pula, Gereja bergerak untuk membenahi dan membangun dirinya sendiri dalam pengajaran (teologi), persekutuan, dan pelayanan, sebagaimana yang telah dijelaskan di atas. Fakta tersebut adalah munculnya, dan bahkan menjamurnya hal-hal berikut ini: Gerakan Zaman Baru, Spiritisme dan Dunia Orang

\footnotetext{
${ }^{34}$ Zaluchum, Reposisi Gereja Abad ke-21, 19.

${ }^{35}$ Zaluchum, Reposisi Gereja Abad ke-21, 20-21.
} 
Mati, End of Time (Akhir Zaman), Sighs and Wonder, Gerakan Reformasi, Pemujaan Nama Yahwe, dan Hyper Grace. Fakta tersebut dapat menjadi acuan bagi Gereja untuk memulai pembenahan diri, melihat diri dan memperkuat diri.

\section{E. Sejarah dan Latar belakang Gereja GSJA CWS}

Secara berturut-turut berikut ini akan dibahas keberadaan GSJA CWS Jakarta yang mencakup: sejarah, perkembangan, dan kegiatannya:

\section{Sejarah Berdirinya}

Pada bulan Juni tahun 1974, Carl Chrisner dan istri tiba di Jakarta sebagai staf dari kedutaan besar Amerika Serikat di Indonesia. Tidak lama kemudian atas bantuan seorang misionaris, James Anderson, Carl setiap minggu melayani di berbagai gereja di Jakarta. Akan tetapi di dalam hatinya, Tuhan sudah menaruh beban untuk merintis pelayanan di antara masyarakat yang berbahasa Inggris di Jakarta. ${ }^{36}$

Pada bulan Oktober tahun yang sama, diadakanlah pertemuan di kediaman missionary James Anderson. Karena sehariharinya Carl Chrisner bertugas sebagai anggota atase pertahanan kedubes AS, dia berkesempatan untuk bertemu dengan bapak Willy Lasut, seorang perwira staf Umum Angkatan Darat RI. Demikianlah rencana pembentukan kebaktian PentakostalKarismatik berbahasa Inggris mulai dirintis. Kemudian Tom Hines, seorang manager bisnis dari Assemblies of God di Indonesia menyatakan kesediaannya untuk bergabung sebagai pelayan musik. Rencana ini mendapat persetujuan dari Wesley R. Hurst, sekretaris Gereja Assembliesof God untuk daerah Timur Jauh. $^{37}$ Dengan pimpinan Roh Kudus, Carl mulai mendekati pimpinan Hotel Indonesia untuk mengunakan salah satu ruang pertemuan yang ada di hotel tersebut, yang pada waktu itu merupakan hotel terbaik di

36 Carl Chrisner, dalam wawancara dengan team penyusun buku sejarah Gereja CWS ke -35 tahun, 27 Agustus 2009.

37 Chrisner, wawancara.
Jakarta. Kebaktian perdana dilakukan pada hari Minggu tanggal 17 November 1974. Pada awalnya jemaat yang hadirrata-rata 20-30 orang. Sekalipun pelayanan ditujukan bagi para expatriate (orang asing), tetapi sebagian yang hadir merupakan orang Indonesia. ${ }^{38}$

Empat puluh tahun yang lampau, Carl Chrisner mendapat tugas datang ke Indonesia bersamakeluarga, sebagai staff Kedutaan Besar Amerikadi Jakarta, dalam kesempatan wawancara langsung beberapa waktu lampau, Carl mengatakan sebagai berikut, "Tuhan mengirim saya ke Jakarta untuk tujuan yang lain, karena Tuhan membakar hati saya untuk mengadakan kebaktian. Tetapi peraturan pada saat itu melarang orang asing (kedutaan) untuk menggembalakan suatu gereja atau denominasi. Namun Tuhan member Hikmat kepada saya, yaitu: agar berbicara kepada para pejabat pemerintahan RI yang berwenang pada saat itu. Maka penjelasan yang saya dapatkan adalah, gereja tidak boleh dibuka, tetapi mengadakan ibadah tidak dilarang. Oleh sebab itu atas prakarsa dan inisitif saya, saya mengadakan ibadah (Worship Service) dalam bahasa Inggris yang ditujukan untuk orangorang asing pada waktu itu yang ada di Jakarta.",39

\section{Perkembangan Gereja CWS Jakarta}

Sejarah Gereja Charismatik Worship Service Jakarta, terbagi menjadi 4 (empat) periode, yaitu:

Pertama: Periode Perintisan. Pada bulan Juni 1974, Carl Chrisner dan istri tiba di Jakarta sebagai staf dari kedutaan besar Amerika Serikat. Pada saat itu, Tuhan menaruh beban di hatinya untuk merintis sebuah pelayanan di antara masyarakat yang berbahasa Inggris di Jakarta. James Anderson turut mengambil bagian untuk membantu Chrisner untuk merintis pelayanan tersebut. Sekitar bulan Juli sampai Oktober 1974, beberapa pertemuan awal dilakukan untuk

\footnotetext{
${ }^{38}$ Majalah Integrity, Edisi Hut CWS ke-35 Tahun, Vol 1, No 1, Tahun 2007, 62.

${ }^{39}$ Majalah Integrity, 67-68.
} 
merencanakan pembentukan kebaktian Pentakosta-Karismatik. ${ }^{40}$

Pada saat perencanaan tersebut, Tom Mines datang dan menyatakan kesediaannya untuk bergabung sebagai pelayan musik. Dalam perencanaan tersebut, kebaktian akan diadakan di Hotel Indonesia, Jakarta. Namun dalam prosesnya, Carl dan Anderson mengalami kesulitan. Berdasarkan kontrak dengan Hotel Indonesia, uang tanda jadi harus dibayarkan sebelum kebaktian diadakan. Carl dan Anderson pada saat itu tidak memiliki dana untuk membayarnya. Kemudian mukjizat pun terjadi. Sebuah Gereja di Auckland, Selandia Baru mengirim surat dan cek yang jumlahnya persis sama untuk membayar sewa hotel. Kebaktian perdana dilaksanakan pada tanggal 17 November 1974, diadakan di Reog Room, Hotel Indonesia lantai 8 yang dihadiri 19 orang, di antaranya dihadiri oleh Bapak Willy Lasut bersama Ibu, Bapak Yopie Poluan ${ }^{41}$ (yang kemudian menjadi bendahara), Ibu Net Lasut, Bapak Wayne Cagle dan Ibu (yang kemudian sempat melayani sebagai Gembala Sidang) serta beberapa orang lainnya. ${ }^{42}$ Sekalipun pelayanan ini ditujukan bagi para expatriate (orang asing), sejak kebaktian perdana sebagian besar yang hadir merupakan orang Indonesia.

Kedua: Periode Pasca Perintisan. Awalnya berdiri Gereja CWS Jakarta, jemaat yang hadir rata-rata 20-30 orang. Tetapi pada tahun 1975 jemaat berkembang luar biasa, sehingga ruangan Reog Room tidak bisa menampung jemaat yang datang beribadah. Ibadah mengunakan bahasa Inggris (English service). Kemudian kebaktian dipindahkan ke ruangan yang lebih besar yaitu Madura Room.

Sejalan dengan perkembangan jemaat, Sekolah Minggu pun dimulai dengan bantuan Ibu Teng (pimpinan sekolah minggu GSJA Batu Tulis). ${ }^{43}$ Sekalipun kebaktian dalam

\footnotetext{
${ }^{40}$ Buku Hut ke-30 Tahun Gereja CWS, 2004, 2021.

41 Carl Chrisner, "Rekaman hotbah Ibadah Minggu Tanggal 12 Juli 2009.

${ }^{42}$ Team PWJ, Buku Pelajaran Pembinaan Warga Jemaat 2 CWS (Jakarta: 2010), 40.

${ }^{43}$ Team PWJ, Buku Pelajaran Pembinaan Warga Jemaat 2 CWS, 42.
}

bahasa Inggris, Sekolah Minggu tetap menggunakan bahasa Indonesia.

Ketiga: Periode Estafet Penggembalaan. Antara tahun 1976-1978 terjadi beberapa pergantian gembala. Pergantian Gembala Sidang dari Pastor Chrisner kepada Pastor Wayne Cagle. Beberapa bulan kemudian (sekitar tahun 1975-1976), Pastor Cagle diganti oleh Pastor Anderson. Sekitar tahun 1976 kembali terjadi penggantian kepada Pastor Curtis Myers, yang kemudian menjadi Gembala Sidang yang paling lama di Gereja CWS Jakarta.

Pada pengembalaan Rev. Curtis Myeer, pertumbuhan Gereja CWS begitu pesat. Jemaat memenuhi ruangan kebaktian. Selain kebaktian hari Minggu jam 10.00, juga diadakan kebaktian tengah minggu pada hari Kamis jam 19.00, dengan acara Penelaahan Alkitab (PA). Pada tanggal 19 Agustus 1979, Pastor Suwandoko Roslim dan Ibu Emma Roslim tiba di CWS untuk mendampingi Mr. \& Mrs. Myers. Pada waktu itu, selain melayani di CWS, Pastor Suwandoko Roslim juga memimpin Jakarta Bible School (Sekolah Alkitab Jakarta). Pada 26-29 September 1979, diadakan kebaktian kebangunan rohani karismatik pertama dengan pembicara Rev. Eugene Ness, bertempat di Hotel Hyatt Aryaduta. Acara ini sekaligus mengawali kepindahan permanen pertama GSJA CWS dari Hotel Indonesia ke Hotel Hyatt Aryaduta. Sejalan dengan ini, kantor Gereja pindah ke Jl. Suwiryo No. 1 Menteng, Jakarta Pusat. Pada 20 November 1983 tempat ibadah GSJA CWS pindah sementara dari Hotel Hyatt Aryaduta ke J1. Bungur Besar, Jakarta Pusat. Ini merupakan kepindahan permanen yang kedua. Pada tanggal 24-27 November 1983, bersamaan dengan itu, diadakan KKR khusus dalam rangka kepindahan ke Jl. Bungur Besar $85 .^{44}$

Keempat: Periode Pengukuhan. Pada tanggal 29 September 1985, GSJA CWS pindah dari Jl. Bungur Besar ke Gedung Kenanga, Jl. Senen Raya 46 Jakarta Pusat. Sejak kepindahan GSJA CWS ke Senen Raya 46, penggembalaan diserahkan oleh Ps. Curtis

44 Team Penyusun Buku Kenangan 30 Tahun CWS, 2004, 8-10. 
Myers kepada Ps. Suwandoko Roslim yang juga memimpin cukup lama hingga tahun sekitar tahun $2011 .^{45}$ Tahun 2011 hingga saat ini penggembalaan dilaksanakan oleh Ps. Piet Hein Mailangkay yang menjadi Gembala Senior.

\section{Latar Belakang Rancang Bangun Teologi Gereja CWS Jakarta}

Sebelum masuk kepada rancang bangun Gereja CWS, ada baiknya memahami dahulu prinsip-prinsip utama yang menjadi ciri Doktrin Gereja CWS Jakarta. Gerakan Pentakosta adalah sebuah gerakan yang muncul sebagai akibat dari sebuah kebangunan rohani yang terjadi di sebuah tempat di jalan Azusa, California, Amerika Serikat.

Sebuah kerinduan yang begitu kuat untuk mengalami pengalaman hidup yang berbeda dan kehidupan rohani yang kuat maka dalam sebuah ibadah terjadilah sebuah manifestasi seperti yang terjadi pada murid-murid di Gereja mula-mula yaitu di mana mereka mengalami baptisan Roh Kudus dan berbicara dalam bahasa-bahasa yang baru (bahasa lidah) (Kis. 2:4. ${ }^{46}$ Peristiwa ini terus berlanjut kepada orang dengan jumlah yang lebih banyak lagi yang mengalami pengalaman tersebut.

Pengalaman ini terus merambah ke berbagai kota-kota di Amerika, hingga akhirnya ke seluruh dunia. Gerakan Pentakosta ini sangat meyakini akan pengalaman baptisan Roh Kudus yang bukan hanya terjadi pada masa lalu saja, tetapi hal itu adalah pengalaman yang masih terus berlanjut. Baptisan Roh Kudus adalah janji Bapa yang diberikan kepada semua orang percaya (Kis. 1:4). Pengalaman Baptisan Roh Kudus ini sangat dibutuhkan oleh setiap orang percaya yang ingin mengalami hidup yang bertumbuh di dalam Kristus, keberanian untuk bersaksi atau memberitakan Injil dan lainnya.

$$
\begin{array}{lrr}
\multicolumn{2}{c}{\text { Orang-orang Pentakosta dalam }} \\
\text { melakukan ibadah, mereka terus }
\end{array}
$$

45 Team Penyusun Buku Kenangan 30 Tahun CWS 15

${ }^{46}$ Team PWJ, Buku 2 Pendididkan Warga Jemaat (Jakarta: 2013), 40-41. mengharapkan pengalaman ini terjadi kepada orang yang belum mengalaminya. Tidak hanya itu saja, mereka juga tetap mempraktekkan bahasa lidah sebagai karunia yang Tuhan berikan untuk membangun. ${ }^{47}$ Karismatik menunjuk serta mengambarkan orang-orang Kristen yang percaya pada manifestasi Roh Kudus yang nyata dalam kehidupan Gereja mula-mula, ${ }^{48}$ seperti mukjizat-mukzijat, nubuat, glossolalia, sebagai pengalaman iman yang masih terjadi sampai masa kini.

Karunia-karunia Roh Kudus merupakan dinamika yang diperlukan untuk kehidupan Gereja Tuhan agar hidup dan bertumbuh, sebagaimana Gereja mula-mula mengalami pertumbuhan dan perkembangan yang luar biasa oleh karena mereka mempraktekkan karunia-karunia yang dikerjakan oleh Roh Kudus. Penekanan akan karunia-karunia Roh tidak dengan sendirinya melupakan bagian lain dari kehidupan Ggereja Tuhan. Kelompok Karismatik tetap menekankan pentinganya penginjilan, pengajaran, dan lain sebagainya sebagai hal penting yang dibutuhkan untuk pertumbuhan dan perkembangan Gereja Tuhan. ${ }^{49}$

\section{Rancang Bangun Teologi Gereja CWS Jakarta}

Ada lima landasan pengajaran utama, yang menjadi ciri khas Gereja CWS Jakarta.

Pertama: Kisah Para Rasul 2:4, Maka penuhlah mereka dengan Roh Kudus, lalu mereka mulai berkata-kata dalam bahasabahasa lain seperti yang diberikan oleh Roh itu kepada mereka untuk mengatakannya."

Kedua: Kisah Para Rasul 8. Filipus sebagai pribadi yang dipenuhi Roh Kudus, dipakai luar biasa, sehingga terjadi kebangunan rohani di Samaria. Tetapi beberapa pengurus Gereja curiga dengan apa yang terjadi saat itu, sampai pada akhirnya mereka melihat dan percaya akan pekerjaan

47 Team PWJ, Buku 2 Pendididkan Warga Jemaat, 43

${ }^{48}$ Bdk. Kis. 2:1-11.

${ }^{49}$ Team PWJ buku 3, Pembinaan Warga Jemaat, dalam Karunia-karunia roh,(,Jakarta: 2013), 20. 
Roh Kudus yang luar biasa, dan banyak jiwajiwa bertobat dan minta dibaptis.

Ketiga: Kisah Para Rasul 9. Kisah pertobatan Saulus menjadi suatu kisah yang dramatis, bagaimana seorang yang menolak Tuhan dan menganiaya pengikut Tuhan dapat diubahkan. Ketika sedang melakukan perjalanan ke Damaskus, ia bertemu Yesus dan menjadi buta; lalu ia dilayani secara khusus. Tuhan pun kemudian mengubahkan namanya menjadi Paulus. Tuhan mempunyai rencana besar untuk dia. Di sini sangat jelas bahwa peranan Roh Kudus sangat penting dalam pertobatan Paulus.

Keempat: Kisah Para Rasul 10. Petrus pergi ke rumah Kornelius, untuk menyampaikan Injil kepada orang-orang non yahudi, dan banyak orang Yahudi tidak suka. Tetapi Tuhan tidak mempedulikan aturan orang Yahudi, karena Tuhan memakai Petrus secara luar biasa melalui khotbah-khotbahnya, yang membawa banyak jiwa datang kepada Yesus. Dalam kisah ini, kuasa Roh Kudus yang penuh urapan menyertai pelayanan Petrus, sehingga banyak orang diselamatkan melalui khotbah-khotbahnya.

Kelima: Kisah Para Rasul 19. Dijelaskan dalam cerita ini, banyak orang di Efesus mengalami baptisan Roh Kudus. Setelah itu mereka mengalami hal-hal yang luar biasa dalam kehidupan mereka.

Berdasarkan penjelasan lima landasan pengajaran utama di Gereja CWS, maka inti utama di dalam Pengajaran Doktrin Gereja CWS yang perlu digarisbawahi adalah:

1. Setelah menerima Tuhan Yesus sebagai Tuhan dan Juruselamat, maka seseorang harus senantisa dipenuhi Roh kudus, sebagai tanda bahwa kita dipimpin Roh Kudus.

2. Sebagai tanda dipenuhi Roh Kudus, maka seseorang mengalami pengalaman rohani secara nyata dalam kehidupannya sehari-hari, karena Tuhan telah mengaruniakan karuniakarunia Roh Kudus kepada setiap orang yang dikehendaki-Nya. Roh Kudus memproses (memimpin) seseorang agar memilki karakter seperti Yesus Kristus, ditandai dengan munculnya buah Roh (Gal. 5:22), sehingga berbagai karakter buruk (Gal. 5:9-21) tidak lagi tampak.

\section{Pengakuan Iman Gereja CWS Jakarta ${ }^{50}$ \\ Ada dua belas Pengakuan Iman Gereja CWS Jakarta.}

Pertama, Alkitab adalah Firman Allah yang tertulis, diilhamkan oleh Roh Kudus, tanpa salah dan mempunyai otoritas atas kehidupan (2 Tim. 3:16-17; Ibr. 4:12).

Kedua, Allah itu Esa, kekal, menyatakan diri dalam tiga pribadi: Allah Bapa, Allah Anak, dan Allah Roh Kudus (Ul. 6:4; Mrk. 12:29; 1 Tim. 2:5).

Ketiga, Tuhan Yesus Kristus itu llahi adanya, lahir dari anak dara Maria (Mat. 1:18-25; Luk. 1:26-31), hidup tanpa dosa, melakukan tanda ajaib dan mukjizat, mati disalib, dikuburkan, hari ketiga dibangkitkan (Mat. 27). Sekarang ada di sebelah kanan Allah Bapa, menantikan saat kembali ke dunia dalam kuasa dan kemuliaan besar (Kis. 1:11; 1 Tes. 4:16; Zak. 14:4).

Keempat, satu-satunya cara penyucian dari dosa adalah melalui pertobatan dan iman di dalam darah Kristus (Kis. 1:37-38; Mat. 9:2; 1 Yoh. 3:16).

Kelima, pembaharuan Roh Kudus adalah mutlak bagi keselamatan pribadi (Yoh. 3:5).

Keenam, baptisan air dengan cara diselamkan (Mat. 28:19; Rm. 6:3-11).

Ketujuh, karya penebusan Kristus di salib menyediakan kesembuhan bagi tubuh dan jawaban bagi kebutuhan manusia seutuhnya, diterima dengan iman melalui doa (Yes. 53:5; Yoh. 15:7).

Kedelapan, pengudusan dikerjakan oleh Roh Kudus yang mendiami orang percaya (Yoh. 4:5; Gal. 5:22; Yak. 6:23).

Kesembilan, baptisan Roh Kudus (Kis. 2:4) diberikan kepada setiap orang percaya yang memintanya. Roh Kudus tinggal di dalam orang percaya, menyanggupkan mereka untuk hidup dalam kesucian.

${ }^{50}$ Team PWJ, Buku 1: Pembinaan Warga Jemaat, dalam Pengakuan Iman (Jakarta: CWS, 2013), 37. 
Kesepuluh, pengangkatan Gereja terjadi pada kedatangan Tuhan Yesus yang kedua kalinya di awan-awan (1 Tes. 4:16, 17).

Kesebelas, kebangkitan manusia, sebagian kepada kehidupan kekal, sebagian kepada hukuman kekal (Kis. 24:15-16; Ibr. 9:27; Rm. 14:10; 2 Kor. 5:10).

Keduabelas, Roh Kudus diberikan kepada setiap orang percaya untuk memperlengkapi mereka dalam pelayanan sesama tubuh Kristus (1 Kor. 12:9; Rm. 12 :7; Ef. $4: 11-12){ }^{51}$

Dari dua belas Pengakuan Iman, akan diuraikan rancang bangun teologi empat unsur pengakuan iman, yaitu: Baptisan Roh Kudus, Karunia Roh Kudus, Keselamatan, Gereja sebagai tubuh Kristus. Adapun pemilihan keempat unsur tersebut, didasari atas kenyataan, selama empat puluh satu tahun keberadaan Gereja CWS.

\section{Baptisan Roh Kudus ${ }^{52}$}

Dalam Pengakuan Iman Gereja CWS, baptisan Roh Kudus adalah sesuatu yang harus dialami oleh setiap jemaat, dan sebagai tanda awal, seseorang dibaptis oleh Roh Kudus yaitu dengan berbahasa lidah. Jadi bahasa lidah identik dengan seseorang telah dibabtis oleh Roh Kudus.

Praktik bahasa lidah sudah ada sejak zaman para rasul, yaitu sejak peristiwa Pentakosta (Kis. 2). Dalam dua peristiwa berikutnya, karunia bahasa lidah juga terjadi pada orang-orang percaya yang bukan keturunan Yahudi, yaitu peristiwa yang terjadi di Kaisarea, di rumah seorang perwira pasukan Italia bernama Kornelius dalam Kisah Para Rasul 10, dan peristiwa yang terjadi di Efesus (Kis. 19). 30.

${ }^{51}$ Team PWJ, Buku 1: Pembinaan Warga Jemaat,

52 Buku 1, 2, dan 3, Pengajaran Pendidikan Warga Jemaat $(P W J)$. Team Penyusun buku Pelajaran PWJ, dibentuk tahun 2010 oleh Gembala Gereja CWS Jakarta (Gembala Senior) yaitu Pastor Suwandoko Roslim, Ph.D. Ada empat orang team penyusun: (almh) Pdt. Lydia Hutapeaa M.Th. (Koordinator), Pdt. Wasis Suseno M.Th, Pdt. Grace Pondege, MA, dan Pdt. Jemmy Lexy, MA.
Pengalaman berbahasa lidah yang terdapat di dalam Kisah Para Rasul inilah yang menjadi dasar munculnya gerakan yang mengutamakan Roh Kudus (saat ini dikenal dengan aliran Pentakosta, dan kemudian Kharismatik). Kelompok ini meyakini bahwa bahasa lidah sebagai sesuatu yang mutlak harus dimiliki oleh seseorang yang telah mengalami baptisan Roh Kudus.

Peter Wagner menjelaskan bahwa, awal gerakan Pentakosta bermula pada tanggal 31 Desember 1900 saat Charles Parham dari Topeka, Kansas, meletakkan tangan atas Agnes Ozman yang mulai berbahasa lidah. Selanjutnya, tahun 1906 terjadi kebangunan rohani yang terkenal di jalan Azusa di bawah pelayanan William Seymour. Sejak peristiwa itu gerakan Pentakosta mengalami kemajuan yang pesat. ${ }^{54}$

Dalam abad 20 gerakan ini mulai dianggap sebagai gerakan yang bertentangan sebagaimana saksi Yehova, Mormon dan Spiritisme, oleh Gereja-gereja fundamentalis di Amerika Serikat. Namun setelah Perang Dunia II saat gerakan Pentakosta mulai banyak mempengaruhi dan masuk ke dalam semua golongan Gereja, maka gerakan Pentakosta ini mulai dapat diterima. Tahun 1960 mulai muncul gerakan Neo-Pentakosta yaitu sejak seorang pendeta Episcopal di Van Nuys, California, yaitu Dennis Bennet, mengalami Roh Kudus menurut cara orang Pentakosta. ${ }^{55}$

Dalam Perjanjian Baru, bahasa lidah berasal dari bahasa Yunani glossa, yang berarti lidah, organ tubuh yang digunakan untuk berbicara, dan kata kerja laleo yang berarti berbicara, berkata, mengeluarkan suara dari mulut. Kedua kata Yunani ini diartikan menjadi glossolalia yang artinya bahasa lidah. Jadi, penggunaan istilah "bahasa roh" kurang tepat untuk digunakan secara luas.

Istilah bahasa lidah, bahasa asing, bahasa roh, dalam PB menggunakan kata

53 William W. Menzies dan Stanlay M Horton, Doktrin-doktrin Alkitab (Malang: Gandum Mas, 1998), 45.

${ }^{54}$ Peter Wagner, Manfaat Karunia Roh (Malang: Gandum Mas, 2005), 65.

${ }^{55}$ Wagner, Manfaat Karunia Roh, 83-85. 
yang sama yaitu $\gamma \lambda \omega \sigma \sigma \alpha$ (glōssa, lidah). Markus 16:17 menulis $\gamma \lambda \omega \sigma \sigma a / s ~ \lambda \alpha \lambda \eta \sigma o v \sigma / \nu$ xalvals [berbicara dengan lidah yang baru]. Kisah Para Rasul 2:4 menulis lain heterais glossais [berbicara dengan lidah yang lain]. ${ }^{56}$ Mulai Kisah Para Rasul 10:45 dan seterusnya tidak ada lagi kata heteros (yang lain) maupun kainos (yang baru), melainkan kata kerja $\lambda \alpha \lambda \varepsilon \omega$ (berbicara) dan $\gamma \lambda \omega \sigma \sigma \alpha$ (lidah). Jadi, baik dalam Kisah Para Rasul maupun surat Korintus menggunakan kata dan ungkapan yang sama yang dewasa ini dikenal dengan $\gamma \lambda \omega \sigma \sigma 0 \lambda \alpha \lambda \alpha_{1}{ }^{57}$

Uraian di atas sejalan dengan pernyataan Paul Enns, yang mengatakan bahwa, bahasa lidah di Kisah Para Rasul dan Korintus adalah sama. Tidak ada bukti yang menyatakan bahwa bahasa lidah di Korintus berbeda dengan yang ada di Kisah Para Rasul. ${ }^{58}$ Atinya, ketika berbicara mengenai bahasa lidah yang ada di dalam kitab Kisah Para Rasul, kita tidak bisa mengabaikan 1 Korintus. Hal ini penting, karena ada yang mengangap bahwa bahasa lidah yang ada di Kisah Para Rasul berbeda atau terpisah dengan yang ada di dalam 1 Korintus. Tujuannya untuk membedakan bahasa ldiah sebagai tanda dan bahasa lidah sebagai karunia. Namun uraian di atas menjelaskan bahwa keduanya adalah sama. Bahasa lidah yang disebutkan dalam Kisah Para Rasul 2 merupakan bahasa-bahasa (bentuk jamak), tidak berbeda dengan bahasa ldiah yang disebutkan di dalam 1 Korintus; keduanya sama-sama tidak dimengerti oleh si pembicaranya.

Dalam Kisah Para Rasul, bahasa itu dimengerti oleh para pendengarnya, sedangkan di dalam 1 Korintus, bahasa itu tidak dimengerti oleh para pendengarnya, sehingga memerlukan orang yang dapat menafsirkannya. Meskipun ada perbedaan yang ditinjau dari sisi pendengarnya, keduanya adalah sama yaitu bahasa lidah yang berasal dari Roh Kudus yang tidak dimengerti

\footnotetext{
${ }^{56}$ Daun, Kekristenan dan Pertumbuhan, 73.

${ }^{57}$ Karunia Bahasa Roh (2006), diakses dari situs http://www.sarapanpagi.org

${ }^{58}$ Paul Enns, The Moody Handbook of Theology, Jilid 1 (Malang: Literatur SAAT, 2006), 336.
}

si pembicaranya dan tidak pernah mereka pelajari. Reinhard Bonke mendefinisikan bahasa lidah sebagai "bahasa sorgawi dan duniawi, yang diucapkan hanya oleh orang percaya seperti yang diberikan oleh Roh Kudus untuk mereka ucapkan., ${ }^{, 59}$

\section{Pandangan Gereja CWS tentang Bahasa Lidah}

Bagi Gereja CWS, bahasa lidahsebagai tanda awal-adalah bukti bahwa seseorang telah mengalami baptisan Roh Kudus. Gereja CWS berpendapat bahwa baptisan Roh Kudus terjadi setelah peristiwa pertobatan, di mana kedua peristiwa tersebut adalah dua hal yang berbeda dan terpisah. Seseorang yang dibaptis dengan Roh Kudus akan menyebabkan Roh Kudus memenuhi orang itu, sehingga dia akan memiliki karunia-karunia Roh, terutama karunia berbahasa ldiah sebagai tanda awal dari kepenuhan Roh.

Peristiwa baptisan Roh Kudus ini dikenal dengan istilah berkat kedua (second blessing) yang ditandai dengan berbahasa lidah. Sebagaimana yang dikatakan Parham bahwa, baptisan Roh harus terbukti secara fisik dengan berkata-kata dalam bahasa lidah (bahasa asing). Pandangan ini mengacu kepada peristiwa di dalam Kisah Para Rasul 2, di mana para rasul yang sebelumnya telah mengalami pertobatan dan menjadi orang percaya, baru berbahasa lidah setelah mengalami kepenuhan Roh Kudus.

Kepenuhan Roh Kudus oleh kelompok ini disamakan dengan baptisan Roh Kudus. Selanjutnya ada kejadian lainnya yang mendukung pandangan second blessing ini, yaitu dua peristiwa yang terdapat di dalam Kisah Para Rasul 10:23-48 dan 19:1-7. Dalam kedua peristiwa tersebut, orang-orang nonYahudi yakni orang-orang percaya di Kaisarea dan orang-orang percaya di Efesus, menerima karunia bahasa lidah setelah mengalami baptisan Roh Kudus.

59 Reinhard Bonke, Mighty Manifestations (Surabaya: Majesty Books Publisher, 2006), 243. 


\section{Karunia-karunia Rohani ${ }^{60}$}

Sesuai dengan namanya, unsur karunia menjadi penekanan yang diutamakan di dalam teologi Gereja CWS. Kata karunia artinya suatu pemberian cuma-cuma dan yang tidak semestinya diberikan; sesuatu yang diberikan kepada manusia yang tidak layak menerimanya. Sesuatu yang berasal dari kasih karunia Allah yang tidak pernah dapat dicapai atau diperoleh atau dimiliki dengan usaha manusia itu sendiri (bdk. Ef. 2:8-9). Karunia rohani diberikan kepada setiap anggota tubuh Kristus (Ef. 4:7; Rm. 12:6). Karunia rohani diberikan untuk memperlengkapi orang-orang kudus bagi pekerjaan pelayanan, bagi pembangunan tubuh Kristus (1 Kor. 12:7; Ef. 4:12; Rm. 12:4-5).

Gereja CWS Jakarta, membagi karuniakarunia rohani sebagai berikut:

1. Karunia Jawatan. Karunia rohani yang bersifat jawatan ini diberikan oleh Allah kepada orang-orang tertentu untuk melayani secara purnawaktu untuk mengurus (menyelengarakan) suatu tugas (pekerjaan) dalam ruang lingkup yang (lebih) luas. Karunia-karunia ini baru terungkap secara sempurna setelah kedewasaan rohani berkembang dalam diri seseorang (Ef. 4:11): rasul, nabi, penginjil, gembala [sidang] (bdk. 1 Ptr. 5:1-11), pengajar.

2. Karunia Pelayanan. Karunia ini berdasarkan kemampuan-kemampuan bawaan, bakat, kepandaian, keterampilan, kekuatan dan kreativitas yang saling berkaitan secara khas di dalam setiap pribadi manusia yang sepenuhnya diserahkan kepada Allah dan dipakai dengan kuasa dan bimbingan Roh Kudus:

a. belas kasihan (Mat. 25:37-40; Mrk. 9:41; Luk. 10:33-37; kis. 9:36-47; Rm. 1:4-8; Yak. 1:27; 2:14-17).

b. keahlian/kreatifitas seni (ekspresi seni bagi keuntungan orang lain:

${ }^{60}$ Team PWJ, Buku 1 Pembinaan Warga Jemaat, dalam Karunia-karunia Roh (Jakarta: CWS, 2013), 37.
Kel. 31:1-11; 2 Sam. 6:12-16; 1

Raj. 7:14; Kel. 30:22-31; 2 Raj. 12:11-13; 2 Taw. 34:9-13; Kis. 18:3). Karunia ini juga memampukan anggota tubuh Kristus untuk dapat mempergunakan tangan dan pikiran mereka untuk mengembangkan Kerajaan Allah melalui cara-cara yang artistik dan kreatif (Kel. 28:3-4).

c. pelepasan (memampukan anggota tubuh Kristus untuk membantu orang-orang yang menderita karena pengaruh roh jahat untuk mengalami kelepasan [Mat. 10:1; 12:28-29; 12:43-45; Mrk. 5:1-20; 9:28-29; 16:17; Luk. 10:17-20; Kis $8: 5-8 ; 16: 16-18 ; 19: 13-16]){ }^{61}$

d. konseling (memampukan anggota tubuh Kristus untuk melayani sesama melalui penghiburan, pengurapan dan penguatan, hingga orang lain tersebut dapat mengalami pertolongan dan kesembuhan [Yoh. 4:1-42; kis 14:21-22; Rm. 12:6-8; 2 Kor. 1:37; 1 Tes. $2: 11 ; 1$ Tim. 5:1]). ${ }^{62}$

e. doa Syafaat, Karunia doa syafaat ini memampukan anggota tubuh Kristus untuk dapat berdoa dalam jangka waktu yang lebih lama, dengan efek yang sangat positif bagi pengembangan Kerajaan Allah (1 Tes. 3:10-13; 2:1-2).

f. memberi tumpangan.

g. murah hati (bdk. Luk. 10:30-37).

h. memberi (bdk. 2 Kor. 8:1-5).

i. administrasi.

j. membantu.

k. musik.

1. kepemimpinan.

m. menasihati.

\section{Karunia yang Bersifat Adikodrati}

Karunia rohani yang bersifat adikodrati ini diberikan "kepada tiap-tiap orang ...

\footnotetext{
${ }^{61}$ Team PWJ, Buku 1 Pembinaan Warga Jemaat,
} 67. 
seperti yang dikehendaki-Nya" (1 Kor. 12:711). Bagaimana Allah hendak menyatakan karunia rohani yang bersifat adikodrati ini bergantung kepada panggilan individu itu dan juga pada keadaan waktu dan tempat yang terkait dengan masing-masing situasi. Roh Kuduslah yang memutuskan untuk memakai orang-orang tertentu dengan karunia tertentu pada waktu-waktu tertentu. ${ }^{63}$

Karunia-karunia tersebut adalah sebagai berikut: berkata-kata dengan hikmat, berkatakata dengan pengetahuan, iman, menyembuhkan, mengadakan mukjizat, bernubuat, membedakan bermacam-macam roh (karunia ini memperlengkapi umat Tuhan dengan pengetahuan yang dalam tentang kebenaran dan penyesatan, dan membawa mereka ke alam supranatural), berkata-kata dengan bahasa roh (memampukan anggota tubuh Kristus untuk menggunakan bahasa yang belum pernah mereka ketahui, baik dalam doa pribadi maupun di depan umum [Mrk. 16:17; kis. 2:1-13; 10:44-48; 19:1-7; Rm. 8:26-27; 1 Kor. 12:10; 12:28-30; 14:4-6; $14: 26-28])^{64}$, dan menafsirkan bahasa roh (memampukan anggota tubuh Kristus untuk menyampaikan pesan yang disampaikan lewat bahasa roh melalui cara yang dapat dipahami (1 Kor. 12:10; 12:27-31; 14:1-5; 14:12-19; $14: 26-28)$.

\section{Keselamatan}

Dalam Gereja CWS Jakarta, konsep keselamatan dijelaskan pada bagian pelajaran Hidup Baru di dalam Kristus, dengan penjelasan sebagai berikut.

Dalam perumpaan anak yang hilang (Luk. 15:11-19), terlihat bahwa semua manusia dahulunya adalah milik Allah. Akan tetapi dengan adanya pelanggaran, maka manusia dinyatakan berdosa kepada Allah. Manusia terhilang dari Allah dan memilih hidup di luar Allah. Dosa telah menghancurkan seluruh eksistensi dan memisahkannya dengan

\footnotetext{
${ }^{63}$ William Barclay, Tafsiran Kitab Roma (Jakarta: BPK Gungung Mulia, 1992), 35. 45.
}

Allah. ${ }^{65}$ Perumpamaan tentang anak yang hilang adalah contohnya.

\section{Hidup bebas dan berpusat pada diri sendiri}

Anak yang bungsu tidak merasa puas dengan hidupnya selama ini. Oleh sebab itu ia datang kepada ayahnya dan berkata: "Bapa, berikanlah kepadaku bagian harta milik kita yang menjadi hakku" (ay. 12). Ia tidak mau dikontrol lagi oleh ayahnya dan berkeinginan hidup bebas. Ia mau mengatur dan bebas menggunakan harta yang menjadi haknya, mau hidup menurut keinginannya sendiri. Ia tidak mau terikat oleh ayahnya dan aturanaturan yang ada di dalam rumah tersebut. Anak bungsu ini hanya memikirkan dirinya sendiri, tidak lagi memikirkan ayahnya yang saat itu masih ada. Inilah gambaran dari seorang yang ada di luar Kristus. ${ }^{66}$

\section{Mengutamakan kenikmatan dunia}

Dalam ayat 13 anak bungsu memakai bagian harta yang ia peroleh untuk mengejar kesenangan dan kenikmatan dunia yang sifatnya hanya sementara. "Beberapa hari kemudian anak bungsu itu menjual seluruh bagiannya itu lalu pergi ke negeri yang jauh. Di sana ia memboroskan harta miliknya itu dengan hidup berfoya-foya." Yang ia pikirkan dan lakukan hanya menikmati, memboroskan hartanya, dan berfoya-foya. Anak bungsu ini tidak mau kesenangan dan kenikmatannya diatur oleh ayahnya. Sikap hidup demikian disebut hedonism, yaitu prinsip hidup yang hanya mengutamakan kesenangan diri sendiri.

\section{Akibat yang didapat}

Pertama, mengalami kesulitan hidup. Akhirnya si bungsu jatuh miskin, melarat dan sengsara (ay. 14). Tidak ada kesenangan, apa lagi kebahagiaan; semuanya telah lenyap. Yang ada hanya kesepian dan sengsara. Situasi ini merupakan gambaran orang di luar dan jauh dari Allah; mengalami kehampaan yang tidak terpuaskan dengan apa yang ada

${ }^{65}$ Roger Stronstad, Theologi Karismatik Santo Lukas (Jakarta: Karismata Publish Publishers, 1999), 21-22.

${ }^{66}$ Team PWJ, Buku 1 Pembinaan Warga Jemaat, 23 
dalam dunia; kegelisahan dan kekuatiran selalu menghantui hidupnya.

Kedua, kehilangan harkat dan martabatnya. Sebagai anak seorang kaya, si bungsu tidak dapat menikmati lagi kekayaan dan kenikmatan yang dimiliki ayahnya. Sebaliknya ia menderita dan terkapar di kandang babi (ay. 15-16). ${ }^{67}$ Semua terjadi karena kesalahannya (dosanya) sendiri, karena ia pergi meninggalkan ayahnya dan tinggal di luar.

Ketiga, terancam kematian. Si bungsu benar-benar mengalami situasi yang gawat. Mau mengisi perutnya saja hanya dengan ampas yang menjadi makanan babi. Itu pun tidak ada yang mau memberikannya; ia teracam kematian (ay. 16). Situasi ini menggambarkan keadaan manusia berdosa pada umumnya; mereka juga teracam kebinasaan karena terpisah dari Allah.

\section{Langkah-langkah Menuju Perubahan}

Akhirnya si bungsu pun sadar akan keadaannya. Ia ambil tindakan untuk berbalik arah. Hidupnya mengalami perubahan total (ay. 22-24). Ia bersedia mengubah cara dan tujuan hidupnya. Semua perubahan yang terjadi ada prosesnya.

\section{Kesadaran sebagai orang berdosa}

Anak bungsu menyadari keadaannya. Katanya: "Betapa banyaknya orang upahan bapaku yang berlimpah-limpah makanannya, tetapi aku disini mati kelaparan." Kesadaran inilah yang membawanya kepada perubahan. Kesadaran itu datang saat ia mengenali apa yang sedang terjadi dengan dirinya; ia telah berdosa: “... aku telah berdosa terhadap sorga dan bapa... (Luk. 15:18).

Dosa adalah pemisah manusia dengan Allah. Dosa adalah pelanggaran hukum Allah (1 Yoh. 3:4). Semua kejahatan adalah dosa. Dosa ialah kegagalan, kekeliruan, kesalahan, kejahatan, pelanggaran, tidak menaati hukum, ketidakadilan, tidak mencapai sasaran yang ditetapkan Allah.

Semua orang sudah berdosa. Alkitab memberitahukan karena perbuatan dosa satu

${ }^{67}$ Team PWJ, Buku 1 Pembinaan Warga Jemaat, orang dosa telah memasuki dunia (Rm. 5:1219; 1 Kor. 15:21, 22). Yang dimaksud satu orang ialah Adam dan akibatnya seluruh dunia berdosa (Rm. 3:23). Oleh karena dosa inilah manusia terpisah dari Allah dan kehilangan kemuliaan Allah (Kej. 3:23-24). Dalam Roma 6:23 dikatakan, bahwa "upah dosa ialah maut...."68 Manusia dituntut untuk bertobat dan kembali kepada Allah, Sang Pemilik hidup. Tanpa pertobatan, tidak ada seorangpun yang berkenan kepada-Nya. Langkah pertobatan itu harus diawali dengan kesadaran akan keberadaannya sebagai orang berdosa, dan kembali hidup bagi Allah.

Dosa merusak hidup manusia, merusak masa depan. Dosa merusak kemampuan manusia untuk berbuat baik maupun menerima yang baik (Yer. 5: 25). Dosa menyebabkan doa tidak sampai kehadirat Allah; Ia tidak mau menolong kita (Yes. 59:12). Dosa menyebabkan hidup manusia mengalami kehampaan karena jauh dari Allah (Rm. 3:23).

\section{Pertobatan}

Setelah menyadari akan dirinya sebagai orang berdosa maka langkah berikutnya adalah langkah pertobatan. Pada hakikatnya, pertobatan adalah perubahan pikiran dan termasuk di dalamnya cara berpikir. Pertobatan yang benar akan menyangkut tiga aspek, yaitu: pikiran, perasaan hati, dan kehendak. ${ }^{69}$

Aspek pikiran. Aspek ini menunjukkan terjadinya perubahan pandangan, yaitu perubahan pandangan terhadap dosa, Allah, dan diri sendiri. Dosa diakui sebagai kesalahan sendiri. Allah diakui sebagai Dia yang secara sah menuntut kebenaran. Manusia yang sudah tercemar tidak berdaya melakukan kebaikan, kecuali dimampukan oleh Allah.

Aspek perasaan. Aspek ini menunjukkan suatu perubahan perasaan. Manusia merasa sedih bahkan lebih jauh, berdukacita, seperti seorang yang ditinggal mati oleh kekasihnya, karena dosa yang diperbuat. Manusia yang

\footnotetext{
${ }^{68}$ Barclay, Tafsiran Kitab Roma, 34.

69 Daniel Lukito, Bertobat (Malang: Literatur
} SAAT, 2007), 34. 
digerakkan Roh Kudus untuk kembali kepada Allah, pasti mendambakan pengampunan dari-Nya.

Aspek kehendak. Aspek ini menunjukkan suatu perubahan kehendak (perbuatan), kecenderungan hati dan tujuan. Ini merupakan tindakan batiniah untuk meninggalkan dosa (Kis. 2:38). Berbicara mengenai perubahan kehendak paling tidak menyangkut dua hal, yaitu: (a) perlunya sebuah pengakuan dosa (Mzm. 32:5; 51:5-6; Luk. 15:21; 1 Yoh. 1:9). (b) ganti rugi karena kesalahan yang dilakukan. Unsur lain yang penting dalam pertobatan ialah iman akan karya penebusan Kristus dan karya Roh Kudus (Yoh. 16:8; 1 Kor. 2:4; 1 Tes. 1:5).

Dari penjelasan di atas, dapat didefinisikan apa itu pertobatan. Bertobat ialah suatu tindakan nyata seseorang yang percaya karya penebusan Kristus, sehingga membawa penyesalan yang dalam akan dosadosanya, dan menghasilkan perubahan cara pandang tentang kehidupan dan mulai mengarahkan tujuan hidupnya sesuai dengan firman Allah (semua ini terjadi dibawah terang Roh Kudus). ${ }^{70}$

Anak bungsu (Lukas 15) melewati tahaptahap ini. Ia mulai menyadari akan kesalahannya, kemudian menyesal akan apa yang telah terjadi; ia bersedia merubah cara pandang tentang kehidupan, dan bersedia kembali kepada bapanya, mengaku bila ia telah berbuat dosa terhadap sorga dan bapa.

Pengakuan merupakan sesuatu yang penting bagi Allah, juga bagi manusia. Landasan pengakuan dosa adalah: pertama: mengungkapkan kesadaran akan kesalahan/dosa yang telah dilakukan (Luk. 15:21); kedua: merupakan tindakan membuka pintu pengampunan (1 Yoh. 1:9); ketiga: merupakan suatu pernyataan yang tersirat, siap untuk berubah menjadi lebih baik. Ini merupakan tindakan iman (Luk.15:17-19).

\section{Pengampunan dan Pemulihan}

Lukas 15:20-21 mengisahkan konteks pengampunan dan pemulihan bagi anak yang hilang. Dalam pengampunan dan pemulihan tersebut, terjadi pembaharuan dan pengudusan.

\section{Pembaharuan}

Lukas 15:24, "sebab anakku ini telah mati dan menjadi hidup kembali, ia telah hilang dan didapat kembali....". Setiap orang yang bertobat mengalami pembaharuan. Hal ini juga ditegaskan Rasul Paulus dalam 2 Korintus 5:17, "Jadi, siapa yang ada di dalam Kristus, ia adalah ciptaan baru: yang lama sudah berlalu, sesungguhnya yang baru sudah datang." Cara hidup lama sudah ditinggalkan, kemudian mengenakan cara hidup baru, selaras dengan kehendak Allah. Pembaharuan menghasilkan kesembuhan; manusia yang lumpuh karena dosa, kini dia disembuhkan (aktif oleh kuasa Allah).

Di samping itu, dalam 1 Yohanes 5:4, dikatakan, bahwa "orang yang lahir dari Allah mengalahkan dunia...."; mengalahkan dunia berarti telah "meninggalkan segala keinginan duniawi dan tidak hidup serta dibelenggu olehnya. Mereka yang mengalami pembarahuan, tidak lagi dikuasai dosa dan hawa nafsu duniawi (bdk. Gal. 5:24-25), tetapi menjadi hamba kebenaran (Rm. 6:1718), dan menjadi manusia baru (Ef. 4:21-24; Kol. 3:9-10).

\section{Pengudusan}

Manusia yang diampuni dan dibaharui, hidupnya harus menunjukkan kekudusan di hadapan Allah dan manusia. Kekudusan datangnya dari Allah dan ia berkehendak agar anak-anak-Nya hidup dalam kekudusan dan kebenaran-Nya; sama seperti anak yang bungsu diberi jubah yang baru (ay. 22), demikianlah Allah memberikan pakaian yang baru-yaitu manusia baru di dalam Yesus Kristus (bdk. 1 Yoh. 1:7; Ibr.13:12).

\section{Pengangkatan anak}

Anak bungsu yang dikatakan sudah mati menjadi hidup kembali, telah hilang dan didapat kembali; dipulihkan kembali sebagai anak Bapa. Hal ini dapat dilihat di mana ia menerima cincin (ay. 22). Sebagai anak, ia tidak menerima roh perbudakan, tetapi

\footnotetext{
${ }^{70}$ Stronstad, Teologi Karismatik Santo Lukas, 46.
} 
menerima Roh yang menjadikan sebagai anak Allah.

\section{Gereja sebagai tubuh Kristus}

Rancang bangun Teologi Gereja CWS Jakarta, sebagaimana dijelaskan dalam buku Pelajaran Pembinaan warga Jemaat 1, sebagai berikut: $^{71}$

Setiap orang percaya merupakan anggota Gereja Tuhan secara universal (tubuh Kristus di seluruh dunia) dan juga sebagai anggota dari sebuah Gereja lokal. Menjadi anggota dalam satu Gereja lokal adalah hal yang sangat penting karena merupakan kehendak Allah bagi setiap orang percaya. Namun demikian, masih ada orang Kristen yang merasa tidak perlu menjadi anggota Gereja lokal. Mereka beribadah secara berpindahpindah (tidak menentap) dari satu Gereja ke Gereja lainnya, dan tidak memiliki komitmen dalam satu Gereja lokal tertentu.

\section{Pentingnya Menjadi Anggota Gereja Lokal (Ef. 2:19; 4:1-16; Ibr. 10:24-25). ${ }^{72}$}

Beberapa alasan mengapa orang percaya harus menjadi satu anggota Gereja lokal: pertama, Allah menghendaki setiap orang bertumbuh secara rohani. Sebagaimana layaknya manusia jasmaniah yang lahir ke dunia dalam wujud seorang bayi, demikian pula halnya dengan manusia rohani. Ketika pertama kalinya seseorang percaya kepada Yesus sebagai Tuhan dan Juruselamat pribadi, ia mengalami proses kelahiran baru, sebagai seorang bayi rohani. Allah mengehendaki setiap orang percaya bertumbuh menjadi dewasa secara rohani. Inilah tanda normal dari kehidupan rohani yang sesuai dengan kehendak Allah (Kol. 2:7; Ef. 4:13); kedua, Allah menyediakan Gereja lokal sebagai sarana untuk pertumbuhan rohani. Seorang bayi memerlukan berbagai unsur penting yang berperan dalam proses pertumbuhannya. Asupan makanan yang bergizi, lingkungan yang bersih dan sehat serta komunitas sosial yang baik, akan sangat berperan penting dan menetukan dalam proses pertumbuhannya. Manusia jasmani

\footnotetext{
${ }^{71}$ Team PWJ, Buku 1, 20-23.

${ }^{72}$ Team PWJ, Buku 1, 25-26.
}

memerlukan makanan, tempat dan orangorang untuk menolongnya bertumbuh, demikian pula halnya dengan manusia rohani; ia memerlukan makanan rohani (Firman Tuhan) yang bergizi dan teratur sesuai kebutuhan, tempat dan lingkungan khusus yaitu sebuah tempat persekutuan dan melakukan aktivitas rohani, serta komunitas orang percaya-yaitu Gereja lokal, yang merupakan komunitas inti orang percaya yang disediakan Allah sebagai sarana pertumbuhan rohani-sehingga dapat berinteraksi secara sosial maupun rohani satu sama lain.

Ada aspek lainnya yang juga menjadi bagian penting dari tindakan Gereja lokal untuk pendewasaan rohani (orang percaya): ${ }^{73}$ Pertama, memberikan makanan rohani bagi pendewasaan iman, yang terprogram dan sesuai dengan kebutuhan jemaat. Penyampaian Firman Allah melalui khotbah ataupun kelas-kelas pemuridan disusun secara terprogram. Kedua, memberikan bimbingan rohani melalui pelayanan doa, kunjungan dan konseling, baik pribadi maupun keluarga, kepada jemaat yang mengalami masalah ataupun kesulitan serta sakit-penyakit dan membutuhkan bimbingan dan peneguhan rohani. Ketiga, memberikan perhatian khusus kepada jemaat dalam kebutuhan-kebutuhan mereka untuk dilayani seperti: pemberkatan nikah, penyerahan anak, pentahbisan rumah, kedukaan dan sebagainya. Keempat, mendidik jemaat untuk menerapkan disiplindisiplin rohani melalui kegiatan ibadah bersama, doa bersama, diakonia (memberi persembahan), membayar persepuluhan, dan bagaimana sepatutnya orang percaya berinteraksi dengan sesamanya. Kelima, memberikan dorongan dan menyediakan peluang bagi jemaat untuk menemukan karunia-karunia rohani mereka serta mempergunakan karunia-karunia tersebut secara maksimal dengan terlibat di dalam pelayanan Gereja.

Allah memakai Gereja lokal sebagai sarana bagi orang percaya untuk menerapkan gaya hidup kerajaan Allah (Kis. 2:41-47).

\footnotetext{
${ }^{73}$ Team PWJ, Buku 3: Pembinaan Warga Jemaat,
} 35 
Gereja lokal mendorong, membimbing dan menyediakan tempat bagi orang percaya untuk mempraktekkan kebenaran Firman Allah sebagai suatu gaya hidup.

Gaya hidup kerajaan Allah yang ditumbuhkan melalui komunitas Gereja lokal:

Beribadah (menyembah) kepada

Tuhan. Orang percaya harus beribadah secara pribadi, dan tetap beribadah bersama dalam komunitas Gereja lokal (Ibr. 10:24-25; bdk. jemaat mula-mula [Kis. 2:46-47]).

Bertumbuh dalam karakter Kristus. Di dalam komunitas Gereja lokal, setiap orang percaya belajar bertumbuh dalam karakter untuk menjadi seperti Kristus. Kisah Para Rasul 2:41-47 menunjukkan sebuah kualitas rohani dari komunitas orang percaya mulamula. Mereka bertekun dalam pengajaran (ay. 42), bersatu dengan sehati di dalam kasih Kristus (ay. 44, 46a), bersukacita dan hidup dalam ketulusan hati (ay. 46b), melakukan hal-hal yang baik, sehingga mereka disukai semua orang (ay. 47). Di dalam Gereja lokal, jemaat Tuhan dibentuk melalui pengajaran Firman Allah maupun interaksi dengan sesama orang percaya yang memiliki keunikan kepribadiannya masing-masing. Gereja lokal sebagai suatu komunitas keluarga rohani menjadi tempat untuk melatih orang percaya menghasilkan buah roh dalam praktek kehidupan.

Melayani Tuhan dan sesama secara internal dan eksternal. Di dalam Gereja lokal, orang percaya dapat melayani baik secara internal (sesama orang percaya) maupun secara eksternal (orang-orang yang belum percaya). Sebagai contoh, pelayanan internal dilakukan oleh jemaat Tuhan mulamula (Kis. 2:41-47). Mereka melayani Tuhan di dalam doa bersama (ay. 42b), belajar pengajaran firman (ay. 42 a), puji-pujian bersama (ay. 47a); saling melayani, menolong sesama yang membutuhkan melalui harta mereka (ay. 44-45), menyediakan rumah mereka sebagai tempat bersekutu secara bergilir (ay. 46); dan penyertaan Allah melalui karunia-karunia Roh Kudus pun dinyatakan (ay. 43); hidup mereka menjadi kesaksian yang baik, sehingga jiwa-jiwa baru terus dimenangkan bagi kerajaan Allah (ay. 47).
Berangkat dari konteks di atas, jemaat dalam satu Gereja lokal didorong, diperlengkapi dan digerakkan melalui program-program misi dan penginjilan untuk melayani secara eksternal yaitu memenangkan jiwa-jiwa yang belum percaya kepada Yesus. Dalam hal ini Gereja lokal menjalankan fungsi baik diakonia (melayani sesama orang percaya) maupun marturia (bersaksi/ menginjil orang yang belum percaya).

Bersekutu. Persekutuan orang percaya diikat oleh persekutuan roh di dalam Kristus. Jemaat mula-mula menunjukkan gaya hidup model ini; mereka bersekutu di dalam doa, pengajaran firman, dan makan bersama dengan ucapan syukur dan pujian kepada Allah. Di dalam persekutuan, ikatan persaudaraan sebagai keluarga Allah diperkokoh. Gereja lokal menjadi tempat Tuhan bersekutu secara teratur dan mengembangkan gaya hidup koinonia dalam konteks yang lebih dalam yaitu sence of belonging — rasa memiliki satu dengan lainnya sebagai saudara di dalam Kristus dan keluarga kerajaan Allah.

\section{F. Kesimpulan}

Mengacu pada hasil penelitian dan serta pembahasan hasil penelitian dan temuan mengenai rancang bangun teologi Gereja CWS Jakarta dalam menghadapi trend isu-isu teologi pertumbuhan Gereja masa kini, maka peneliti membuat kesimpulan sebagai berikut:

Pertama, sudah saatnya Gereja CWS Jakarta menyusun model rancang bangun teologi yang baru, supaya lebih lengkap dan komprehensif sesuai dengan kebutuhan jemaat dalam menghadapi trend isu-isu teologi pertumbuhan Gereja. Oleh karena itu, Gereja CWS Jakarta perlu membentuk team kerja yang terdiri atas para hamba Tuhan yang berkompeten dan handal dalam bidang teologi, yang memiliki SDM, mampu bersinergi, dan berkomitmen membangun bersama (berkontribusi), dengan memperhatikan unsur-unsur yang sudah ada, seperti: (1) Gembala Senior sebagai pemimpin Gereja yang dipercaya untuk mengembalakan Gereja CWS Jakarta; (2) Bergantung pada 
warisan teologi yang bersumber dari aliran Pentakosta, dengan warisan pengajaran dari para pendiri Gereja CWS Jakarta; (3). Karya Roh Kudus, ditambah unsur yang lain seperti: Alkitab (sumber kebenaran), eklesiologi dan budaya. Diharapkan team yang dibentuk oleh Gembala Senior dapat merancang bangun model teologi yang baru, sesuai dengan konteks kekinian bagi kehidupan bergereja dan bermasyarakat.

Kedua, melihat kenyataan bahwa Gereja CWS Jakarta belum dapat mengantisipasi menghadapi trend isu-isu teologi pertumbuhan Gereja masa kini, maka sudah saatnya Gereja CWS mengintrospeksi dan mengevaluasi secara menyeluruh tentang kondisi zaman, dan bagaimana menyikapi pengaruh atau masuknya trend isu-isu teologi pertumbuhan Gereja di dalam Gereja, dan bersikap terbuka agar mampu mengubah sesuatu yang sudah ada sesuai dengan dinamika Gereja kekinian.

Ketiga, ada jemaat-jemaat Gereja CWS Jakarta tidak lagi beribadah, karena mereka mencari Gereja di luar untuk memenuhi rasa haus dan dahaga, memenuhi kebutuhan spiritual dan kehidupan keimanannya. Gereja CWS tidak boleh terlena dan masih menganggap sebagai Gereja yang diminati atau disukai seperti kondisi pada tahun 80 -an atau 90-an (menjadi trendsetter). Pada faktanya, Gereja-gereja di Jakarta pada zaman itu, telah mengalami perubahan yang disebabkan oleh arus perubahan zaman. Hal ini menjadi catatan penting bagi Gereja CWS. Jika tidak berani mengubah dari model rancang bangun teologi yang lama kepada model rancang bangun teologi yang baru, terbuka kemungkinan yang sangat besar bahwa Gereja CWS akan ditinggalkan oleh jemaatnya.

Keempat, Gereja CWS Jakarta, tidak hanya memperhatikan pertumbuhan secara kuantitatif (pertumbuhan dari segi jumlah kehadiran jemaat dalam ibadah raya), memperhatikan pembangunan sarana dan prasarana, tetapi juga perlu memperhatikan pertumbuhan secara kualitatif (kualitas iman dan pengajaran teologi [doktrin]), yaitu dengan memperhatikan pertumbuhan sumber daya manusia, dengan mengajarkan kebenaran firman Tuhan lebih dalam dan serius (ajaranajaran yang sehat sekaligus melawan ajaranajaran negatif), melakukan pemuridan, mengadakan training atau pelatihan bidangbidang yang dibutuhkan dalam pengembangan pelayanan. Dengan demikian aspek manusia yang lebih diperhatikan, bukan aspek fisik atau non-spiritual. Bila jemaat bertumbuh secara kualitatif, pertumbuhan secara kuantitatif akan tercapai juga. Sebaliknya, bila Gereja CWS Jakarta hanya mengejar pertumbuhan kuantitatif, sangat sulit baginya untuk dapat eksis dalam memasuki usia Gereja yang ke 42 tahun.

Kelima, diperlukan berbagai upaya nyata untuk membangun atau menyusun model rancang bangun teologi Gereja CWS yang baru, supaya jemaat memiliki landasan yang kuat, baik dalam pengajaran doktrin yang alkitabiah (seperti Soteriologi) kepada jemaat, dan tidak hanya sebatas karunia-karunia Roh Kudus yang menjadi doktrin utamanya.

Keenam, secara terus-menerus mengupayakan keseimbangan dalam menyusun model rancang bangun teologi yang baru, karena model lama cenderung menekankan pada karya Roh Kudus saja. Padahal, ada unsur lain yang juga tidak kalah pentingnya, supaya semuanya menjadi seimbang.

Ketujuh, Gereja CWS Jakarta perlu memperhatikan penggunaan dana; tidak hanya digunakan untuk untuk pembelian aset-aset Gereja, tetapi lebih memperhatikan pengunaan dana untuk aspek pertumbuhan sumber daya manusia, pembinaan rohani (iman), teologi, dan pemahaman Alkitab yang sesuai dengan dinamika gerakan Tuhan pada masa kini.

Kedelapan, dengan menyusun model rancang bangun teologi yang baru, Gereja CWS dapat menghadapi pengaruh negatif trend isu-isu teologia pertumbuhan Gereja, sehingga jemaat dapat (memperoleh hasil) sebagai berikut:

1) menemukan dan memiliki keyakinan yang kuat mengenai rancang bangun teologi Gereja CWS yang baru dan baik sesuai dengan kebenaran Alkitab; 
2) menyeberangkan terus-menerus rancang bangun teologi Gereja CWS kepada Jemat;

3) mengevaluasi secara kontinu perkembangan model rancang bangun teologi Gereja CWS, agar mengikuti dinamika dan perkembangan trend isuisu teologi, sehingga jemaat memiliki pijakan dan landasan pengajaran teologi yang solid, baik, dan tidak tertarik dengan trend isu-isu teologi pertumbuhan Gereja yang sedang berusaha untuk menarik jemaat untuk meninggalkan Gereja. Gereja CWS Jakarta perlu secara potensial memberikan model rancang bangun teologinya sebagai pegangan dan kekuatan kepada jemaatnya, yaitu teologi yang theosentris. Itulah landasan hidup orang percaya. Selain itu, Gereja CWS perlu memberikan perhatian serius dan dorongan bagi para pendeta dan hamba Tuhan untuk terus-menerus belajar teologi secara formal. Tujuannya adalah agar mereka dapat mengembangkan konsep berpikir (pemikiran) teologis, dapat mengikuti dinamika teologi kekinian-tanpa harus meninggalkan asas mula-mula - serta dapat mengetahui gerakan Allah dari masa ke masa dalam menghadapi trend isuisu teologi pertumbuhan Gereja masa kini.

\section{KEPUSTAKAAN}

Barclay, William, Tafsiran Kitab Roma. Jakarta: BPK Gungung Mulia, 1992.

Bonke, Reinhard, Mighty Manifestations. Surabaya: Majesty Books Publisher, 2006.

Brown, Colin, Filsafat dan Iman Kristen. Jilid 1. Surabaya: Momentum, 2008.

Buku Hut ke-30 Tahun Gereja CWS, 2004.

Chrisner, Carl, dalam wawancara dengan team penyusun buku sejarah Gereja CWS ke -35 tahun, 27 Agustus 2009.
Chrisner, Carl, Rekaman hotbah Ibadah Minggu Tanggal 12 Juli 2009.

Conner, Kevin J., A Practical Guide to Christian Belief: Pedoman Praktis tentang iman Kristian. Malang: Gandum Mas, 2004.

Creswell, John W., Research Design: Pendekatan Metode Kualitatif, Kuantitatif, dan Campuran, terj. Achmad Fawaid dan Rianayati K. Pancasari. Yogyakarya: Pustaka Pelajar, 2016.

Daun, Paulus, Bidat Kristen dari Masa ke Masa. Manado: Yayasan Daun Family, 1999.

Enns, Paul, The Moody Handbook of Theology, Jilid 1. Malang: Literatur SAAT, 2006.

Jones, W. T. dan Robert J. Fogelin, A History of Western Philosophy: The Twentieth Century to Quine and Derrida. Orlando: Harcourt Brace College Publishers, 1997.

Kamus Besar Bahasa Indonesia (Jakarta: Departemen Pendidikan Nasional, 2001).

Karunia Bahasa Roh (2006), diakses dari situs http://www.sarapanpagi.org

Lukito, Daniel Lukas, Bertobat. Malang: Literatur SAAT, 2007. . Pengantar TeologiTeologi Kristen. Kalam Hidup, Bandung, 1996.

Lumintang, Stevri I., Diktat TeologiTeologi, 7.

Keunikan Teologi Kristen di Tengah Kepalsuan. Batu: Departemen Literatur PPII, 2013.

Majalah Integrity, Edisi Hut CWS ke - 35 Tahun, Vol 1, No 1, Tahun 2007.

Menzies, William W. dan Stanlay M Horton, Doktrin-doktrin Alkitab. Malang: Gandum Mas, 1998.

Minderop, Albertine, dalam Pragmatisme dalam Falsafah Masyarakat Amerika. Jakarta: Obor, 2005.

Moleong, Lexy J., Metodologi Penelitian Kualitatif. Edisi Revisi. Bandung: Penerbit PT Remaja Rosdakarya, 2010.

Pakcer, J. I., God's Plans for You. Jakarta: Momentum, 2004. 
Sihombing, Lotnatigor, Bahan Ajar Teologi: The Doctrin of God. Batu: 1989.

Stronstad, Roger, Theologi Karismatik Santo Lukas. Jakarta: Karismata Publish Publishers, 1999.

Sugiyono, Metode Penelitian Pendidikan Pendekatan Kuantitatif, Kualitatif, dan $R \& D$. Bandung: Alfabeta, 2008.

Sutanto, Hasan, Hermeneutik: Prinsip dan Metode Penafsiran Alkitab. (Malang: SAAT, 1986.

Team Penyusun Buku Kenangan 30 Tahun CWS. 2004.

Team PWJ, Buku 3, Pembinaan Warga Jemaat, dalam Karunia-karunia Roh .Jakarta: 2013.

Team PWJ, Buku 1: Pembinaan Warga Jemaat, dalam Pengakuan Iman. Jakarta: CWS, 2013.

Team PWJ, Buku 2 Pendididkan Warga Jemaat. Jakarta: 2013.

Team PWJ, Buku Pelajaran Pembinaan Warga Jemaat 2 CWS. Jakarta: 2010.

Van den End, Th., Harta dalam Bejana: Sejarah Gereja Ringkas. Jakarta: BPK Gunung Mulia, 1987.

Wagner, Peter, Manfaat Karunia Roh. Malang: Gandum Mas, 2005.

Walker, Williston, A History of Christian Church. Harvard: Scribner Publisher, 1998.

Zaluchum, Reposisi Gereja Abad ke-21. 